\title{
THE EXCAVATION OF PHUM SOPHY 2009-2010: AN IRON AGE SITE IN NORTH- WEST CAMBODIA
}

\author{
Dougald O’Reilly ${ }^{1}$, Louise Shewan ${ }^{2,3}$, Kate Domett ${ }^{4}$, Jennifer Newton ${ }^{4}$, Damian Evans ${ }^{5}$, Voeurn \\ Vuthy $^{6}$ and Nancy Beavan ${ }^{7}$
}

\footnotetext{
${ }^{1}$ The Australian National University, Canberra, 2601 Australia, ${ }^{2}$ Monash-Warwick Alliance, Monash University, Melbourne 3168 Australia, ${ }^{3}$ Sydney Medical School, University of Sydney, Sydney 2006 Australia, ${ }^{4}$ James Cook University, Townsville, Australia, ${ }^{5}$ École Française d'Extrême Orient, Siem Reap, Cambodia, ${ }^{6}$ Ministry of Culture and Fine Arts, Phnom Penh, Cambodia, ${ }^{7}$ University of Otago, New Zealand

Corresponding author: Dougald O’Reilly dougald.oreilly@anu.edu.au
}

\begin{abstract}
Excavations were undertaken at the village (phum) of Sophy in Banteay Meanchey Province, north-west Cambodia over two field seasons in two separate areas in 2009 and 2010. The remains of twenty individuals were found in 14 mortuary contexts with individuals interred with a range of burial goods including ceramic vessels, stone and glass beads, iron and bronze artefacts and faunal remains. The site dates to the Iron Age (dates spanning the period c. 87-526 AD) and is surrounded by the ruins of later, Pre-Angkorian temples and their associated ponds. Excavation and research has revealed Sophy to be a prehistoric agricultural village in which the inhabitants exploited a wide-range of habitats and engaged in inter-regional exchange. The results of these investigations are presented here incorporating a description of the excavation, preliminary discussion of the material assemblage and demographic data obtained from the mortuary contexts.
\end{abstract}

\section{INTRODUCTION}

The excavation of the village of Sophy, located in in O'Chrov District, Banteay Meanchey Province, northwest Cambodia was undertaken as part of an Australian Research Council funded project entitled "History in Their Bones: A diachronic, bio-archaeological study of diet, mobility and social organization in Cambodia." The project comprised an international multidisciplinary collaboration combining palaeoanthropology, isotopic analysis, radiocarbon dating and archaeological research to create a broad characterisation of past populations in Cambodia and to investigate continuity or change through time.

The village of Sophy (Figure 1) was selected for excavation based upon reports of extensive illegal excavations at the site that had unearthed evidence of prehistoric occupation. The extent of the looting made selection of a suitable, undisturbed area of ground to excavate difficult to locate. In 2009, in consultation with local officials it was decided to excavate on the north-east side of the mound within the grounds of the Buddhist monastery, Chrom Prasat Sophy. The monastery did not sit on the prehistoric mound but the excavation unit lay on the edge of the mound and the majority of the village houses were located atop the mound. A second excavation season was conducted in 2010 with the unit located near the centre of the village (Figure 2).

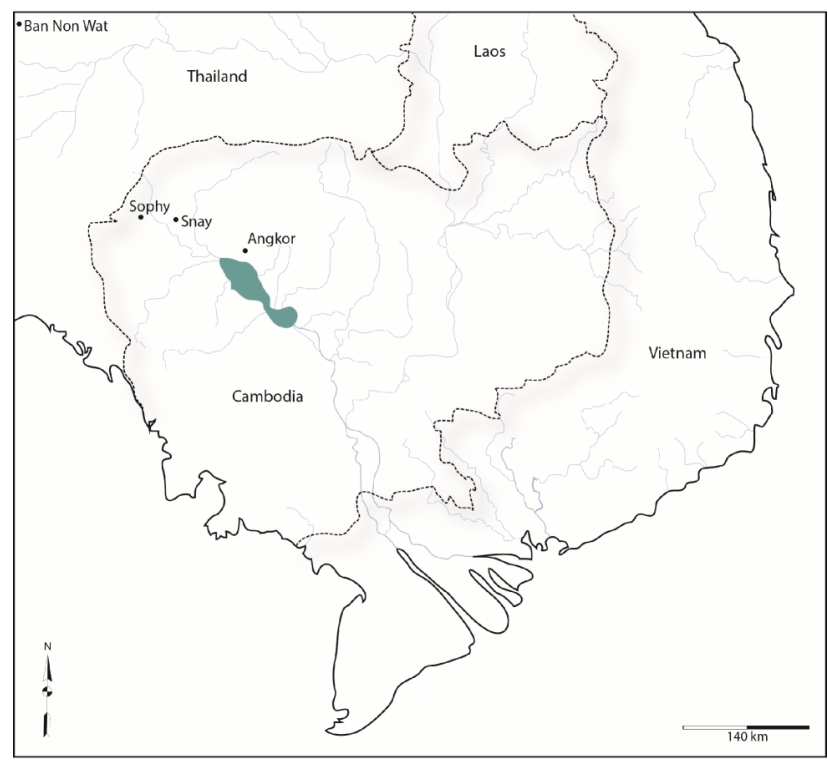

Figure 1: Map of Cambodia showing Sophy.

\section{EXCAVATION SEASON 1}

\section{Unit 1}

An initial test excavation unit (Unit 1) was established adjacent to the western wall of the Chrom Prasat Sophy at N13.38.35.7, E 102.49.59.5. The unit measured $3 \mathrm{~m}(\mathrm{~N}-\mathrm{S})$ x $5 \mathrm{~m}(\mathrm{E}-\mathrm{W})$ with an extension measuring $1 \mathrm{~m}(\mathrm{~N}-\mathrm{S})$ × $2 \mathrm{~m}$ (E-W) extending off the western edge of the $3 \times 5 \mathrm{~m}$ unit. Excavation began on December 8th, 2009. Standard procedures were followed in the excavation of Unit 1 in that $10 \mathrm{~cm}$ spits were removed and screened in $2 \mathrm{~mm}$ mesh 
screens. Changes in soil colour during excavation were designated by a change in the Layer number. The top layer was Layer 1 followed by the spit number (i.e. Layer 1 spit 1 is designated 1:1). Archaeological features are denoted by an ' $\mathrm{F}$ ' in the text following (i.e. F1, F2 etc.). The initial layers of Unit 1 rendered abundant modern ceramic sherds and some animal bone.

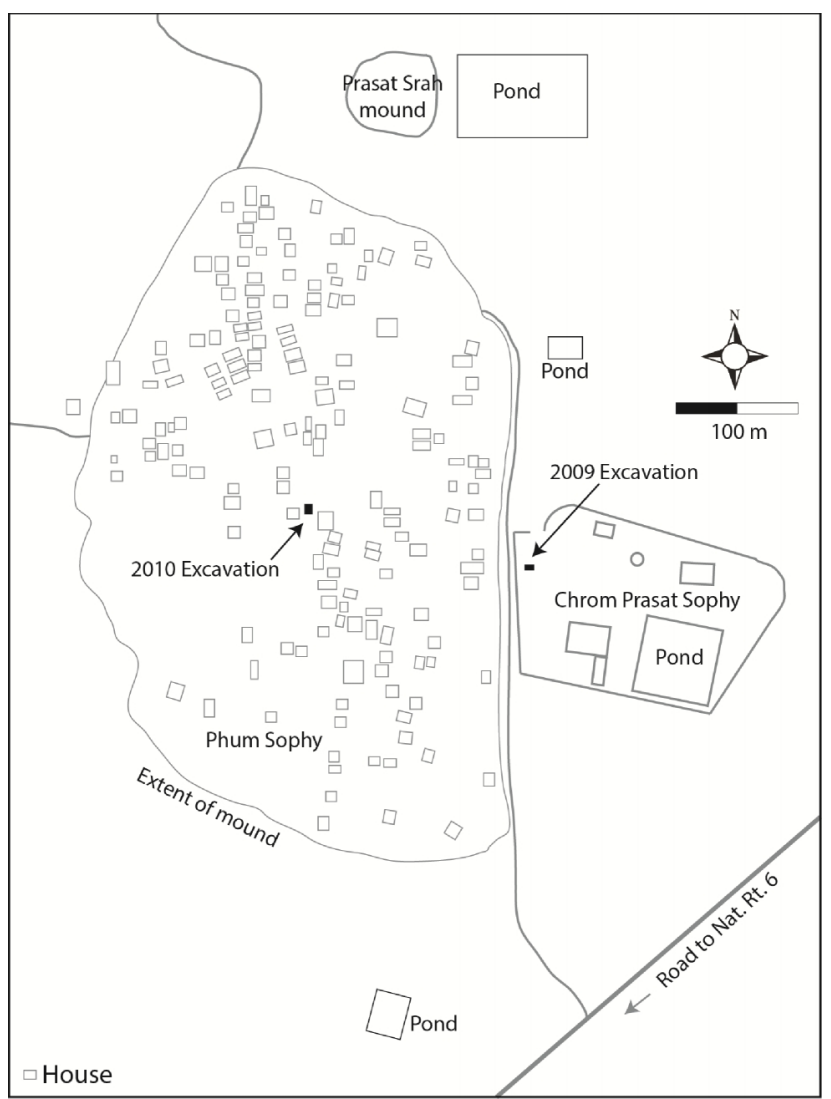

Figure 2: Map of village of Sophy showing excavation units

Layer 1

No artefacts aside from ceramic sherds were encountered in the first two spits, nor were any features uncovered. In the third spit, (1:3) a shallow post-mould was uncovered in the south-east corner of the unit and nearby a fragment of Carnelian bead. Ceramic sherds and animal bone were uncovered along the middle of the north baulk. Layers 1:4-1:5 were unremarkable and devoid of features. A human burial, labelled Mortuary Context $3^{1}$, was identified in 1:6 (c. $52 \mathrm{~cm}$ below the surface) near the centre of the unit (Figure 3). The full burial assemblage will be described in detail in the Mortuary Contexts section below.

\footnotetext{
${ }^{1}$ The unit was excavated in sections and mortuary contexts were encountered at different layers. For ease of explanation these sections have been collated and the Mortuary Contexts are therefore numbered out of sequence.
}

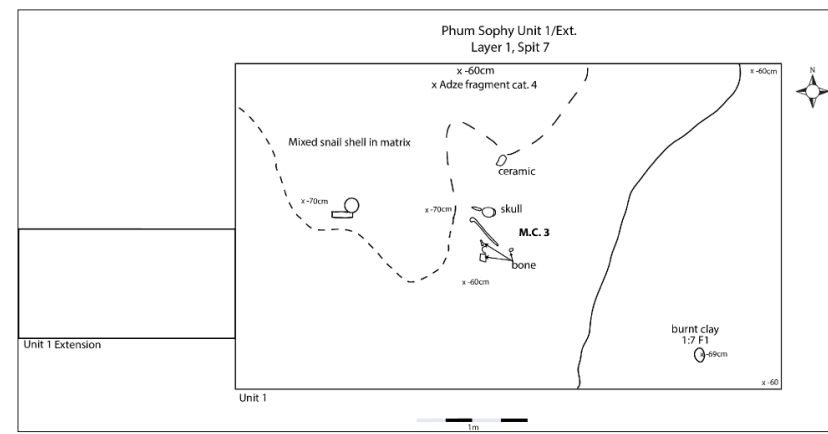

Figure 3: Plan of Unit 1 Layer 1:7, Sophy.

In 1:7 a feature (F2) containing large quantities of snail shell was uncovered along the northern baulk extending into the unit by $2 \mathrm{~m}$. The feature also contained ceramics and a stone adze fragment. A glass bead and a thick ceramic scatter containing several lumps of burnt clay was also identified in 1:7. A small bronze bangle was uncovered in 1:8 in the southwest of Unit 1 and a small bronze ring was found in 1:8 from above some burned clay lumps near the centre of the unit. A piece of iron slag was also encountered in the north-east corner of the unit in 1:8. Feature 1 in Layer 1:9, a darker area of soil running from north to south along the east side of the unit rendered a number of artefacts including glass beads an iron artefact and a clay pellet. Substantial amounts of ceramics and animal bones were also found within this feature. In the south-east corner of the unit a substantial feature (1:9 F3) was uncovered c. $84 \mathrm{~cm}$ below surface and comprised lumps of highly fired clay, an animal bone and a large pot fragment. This feature appears to be either an industrial or a cooking area and the former assumption may be supported by the presence of lumps of fired, highly ferrous laterite in the layer above the feature. After 1:9 the soil colour changed to a mottled orange colour and a new layer was assigned (Layer 2).

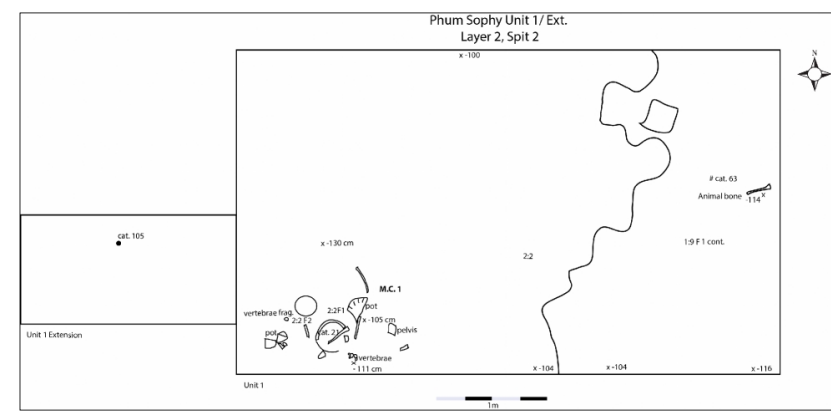

Figure 4: Plan of Unit 1 Layer 2:2, Sophy

Layer 2

A mottled area covered a large portion of the excavated unit but was bounded to the east and west by darker soil. Several small glass beads were discovered in 2:1 and a good amount of ceramics continued to be uncovered as well. In the south-western section of $2: 2$ a scatter of ce- 
ramic sherds around a post mould appeared and a collection of human remains, described below, were discovered and labelled Mortuary Context 1 (Figure 4).

In 2:3 several distinct features were recognized in the eastern part of the unit some of which were clearly post moulds. These amorphous and post mould features (F1-6) returned only fragments of ceramic upon excavation. Mortuary Context 2 was uncovered in the north-west section of Unit 1 in this spit, described below (Figure 5).

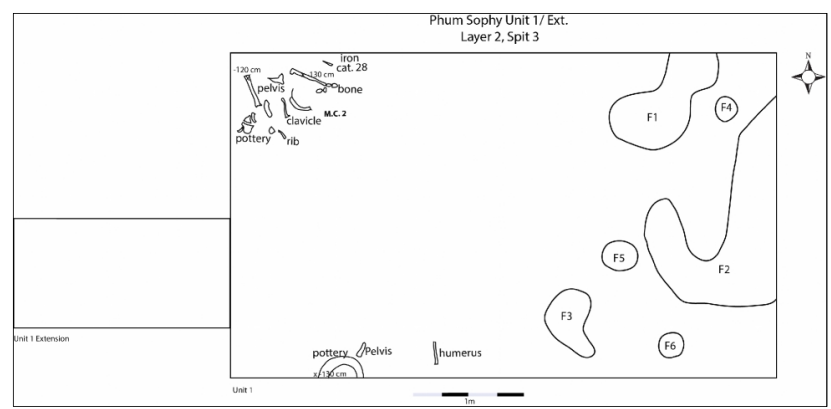

Figure 5: Plan of Unit 1 Layer 2:3, Sophy.

In 2:4 Unit 1 a feature $(2: 4 \mathrm{~F} 1)$ containing a set of four 'nested' pots each smaller and of thinner walls than the last was discovered. A fragment of bronze bangle and a bell were uncovered and a worked shell ornament, a spindle whorl and a piece of shell that likely represents a mortuary offering. A curved iron knife was found below these pots. As this was thought to represent a burial, Unit 1 was extended to the west (see Unit 1 Extension, below).

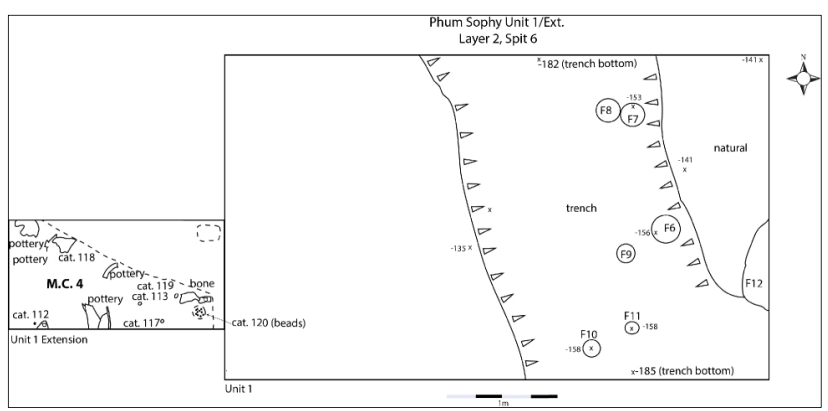

Figure 6: Plan of Unit 1 Layer 2:6, Sophy.

Four circular post moulds appeared in 2:5 (Features 1, 2, 4 and 6) and a large linear feature ran across the unit from north to south $(2: 5 \mathrm{~F} 3)$ that cut into the natural, noncultural soil at the base of the unit. A large ceramic vessel in association with a piece of iron and numerous ceramic sherds came from this feature which appears to be a ditch or trench the bottom of which reached $180 \mathrm{~cm}$ below surface. Natural soil was reached across the main unit with the appearance of a hard yellowish soil with lateritic inclusions and no material culture (Figure 6). This surface was found variably to be $130 \mathrm{~cm}$ and $160 \mathrm{~cm}$ below surface.

\section{Unit 1 Extension}

As there was a likely burial found near the bottom of Unit 1 along the west baulk the unit was extended. This extension was labelled Unit 1 Ext. This new unit was placed 50 $\mathrm{cm}$ north of the southwest corner of Unit 1 and extended 2 $\mathrm{m}$ to the west and $1 \mathrm{~m}$ north-south. There were no features apparent but similar numbers of ceramic sherds and animal bones were found as Unit 1. There was a slight change in soil colour at 2:1 but not as apparent as in Unit 1 , this due, likely to the presence of a mortuary feature, labelled Mortuary Context 4 which is described below. The baulks of Unit 1 and the extension are illustrated in Figure 7.

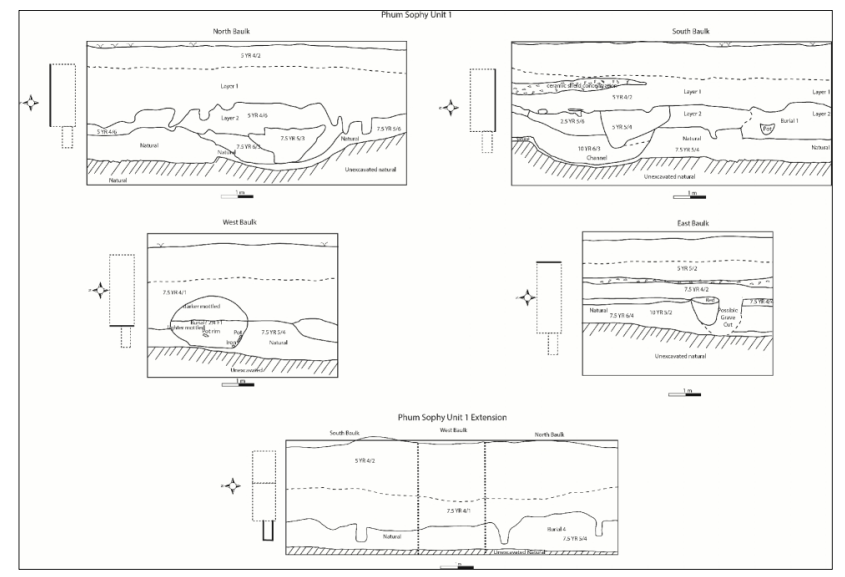

Figure 7: Stratigraphic plan of Unit 1, Sophy.

\section{EXCAVATION SEASON 2}

\section{Unit 2}

In January, 2010 an excavation unit (Unit 2) measuring measuring $5 \mathrm{~m}(\mathrm{~N}-\mathrm{S}) \times 3 \mathrm{~m}(\mathrm{E}-\mathrm{W})$ was located within the village of Sophy at N13.38.37.5 E 102.49.54 (Fig.2). The excavation season revealed a series of rich burials (labelled as Mortuary Contexts 5-14) with accompanying grave goods such as carnelian and agate beads, glass beads, iron tools and bronze implements, bronze jewellery and different forms of ceramic.

Layer 1

The first $20 \mathrm{~cm}$ represented modern occupation and deposits. The surface of Layer 1:3 has some disturbance (possibly looting) and charcoal was present in the northwest corner of unit. A number of features were apparent on the surface of spit 4 . These include some irregular features 1:4 F2, F3, F4 and a large feature, F1 extending from the east wall toward west. F3, made up of a grey sticky mottled soil, was sectioned to $16 \mathrm{~cm}$ below the surface of 1:4 and rendered animal bone and a small bronze bangle fragment. Layer 1:4 F2 is a pit containing some animal bone and pottery and is about $28 \mathrm{~cm}$ deep. A tiny orange glass bead was recovered from F2. F3 and 4 terminated $10 \mathrm{~cm}$ below the surface of 1:4. The faunal remains recovered in Layer 1:4 included water buffalo, an antler core, and muntjac (a femur, a phalanx, a molar and 
two metatarsus). Layer 1 F3 contained pig remains (six skull fragments, a humerus, a rib, and two metatarsals) and a cattle molar.

Layer 1:5 has just two features, one oblong extending out of east baulk in the south of the unit. F2 is in the middle of the north part of the unit. F2 revealed a large grindstone and two pig radii, four pig skull fragments, and a carp vertebrae. Near the south wall a chunk of what appears to be highly heated clay, smooth on one side was found, possibly a furnace fragment was identified. A small bronze fragment was found nearby and a piece of slag was found at the north end of unit. This spit contained a range of faunal material including pig (a canine, two humeri, a phalanx and two ribs), a turtle (a plastron and mandible), a sambar deer (molar), the cleithrum of a catfish, and cattle remains (a radius, tibia, metatarsus, three femurs, a rib, a molar and a phalanx).

There was a decrease in the amount of ceramics recovered in Layer 1:6, however, a large fragment of pot sherd was recovered from the north-west wall. In the south part of the unit, a kendi spout was identified c. 55 $\mathrm{cm}$ below surface. Bronze fragments and a basalt debitage fragment nearby also appeared. Only two features were identified, both along the east baulk. F1 was a semicircular feature $45 \times 100 \mathrm{~cm}$ ( $8 \mathrm{~cm}$ deep) and F2 was located to the south and measured $40 \times 40 \mathrm{~cm}(9 \mathrm{~cm}$ deep). The only faunal remains recovered in this layer was a molar belonging to a sambar deer.

Five features were apparent on the surface of Layer 1:7. F1 was a $5 \mathrm{~cm}$ deep, circular feature containing burnt clay located $60 \mathrm{~cm}$ below surface. F2 was a slightly larger circular feature with ceramics and loose chunks of burnt clay which reached a depth of $28 \mathrm{~cm}$. On the west wall at 1:7 F3 contained broken pottery and faunal remains. The latter comprised; pig (skull fragments, four molars, three phalanges, an ulna, a femur, a mandible and 52 rib fragments); and sambar deer (a molar, a calcanus, a phalanx, a tibia, part of a maxilla and two skull fragments). Civet remains (a femur, vertebra and pelvis) were also found along with the pectoral spines from a blackskin catfish and an Asian red tail catfish and a dentary from a swamp eel. F5 was $10 \mathrm{~cm}$ in depth but contained no artefacts. Aside from that recovered from the features, there was a considerable amount of faunal material found in Layer 1:7 including the carapace and plastron of turtle, pig remains (a calcanus, vertebrae, molar, incisor, femur, and scapula), cattle (pelvis, rib, and an ulna), chicken (tibia), and hog deer (rib and metatarsus). Fish remains included the pre-maxilla and pectoral of a catfish, the dentary of a bronze featherback, and the vertebra and articular from a giant snakehead.

In 1:8 one feature was identified, circular in plan, about $20 \mathrm{~cm}$ in diameter and less than $10 \mathrm{~cm}$ in depth. The feature contained lumps of burnt clay, pottery fragments and a buffalo molar. Two iron 'digging implements' were found in this spit at $80 \mathrm{~cm}$ below surface, one atop the other. The faunal remains from 1:8 included muntjac (a molar, metacarpal and metatarsus), cattle remains (a calcanus, vertebra, a phalanx, tibia and rib), and pig bones (nine ribs, a partial skull, a phalanx, vertebrae and a humerus). The soil colour changed after the removal of 1:8 turning to a lighter grey colour and so the Layer designation was changed.

\section{Layer 2}

From Layer 2 oblong features that later surrendered human remains and associated grave goods began to be uncovered. Layer 2:1 contained two features, F1 was an oblong feature in the center of the unit that contained an iron implement. The feature ran $1.10 \mathrm{~m}$ east-west and 40 cm north-south. F2 was a faintly defined feature in the south-west part of the unit and contained a bronze bangle and a pot and some ceramic sherds as well as some bone fragments. This feature turned out to be a human burial and was labelled Mortuary Context 5 (see below). The faunal material from 2:1 comprised cattle (a calcanus, four humeri, and three ribs) and pig bones (a humerus and vertebrae).

Layer 2:2 contained two features, F1 was located in the south-west corner of the unit and F2 was a large feature in the north-west part of the unit. From within F2, a decorated but broken bone bangle and an orange, glass, indo-pacific seed bead was recovered. Faunal material comprised pig remains (three ribs, two canines, a phalanx, a vertebra and a calcaneus), and eight cattle femora.

Layer 2:3 contained just two features, a darker area in the north-east corner of the unit and a small (c. $20 \mathrm{~cm}$ diameter) post mould along the east baulk in the south. Neither feature revealed any artefacts. Some loose bone was uncovered at $100 \mathrm{~cm}$ below surface in the southwest corner of the unit in this spit. The faunal remains included a cattle rib, two molars and one vertebra.

Layer 2:4 was reached at c. $110 \mathrm{~cm}$ below surface. Five features were identified. F1 was located in the southwest corner of the unit. F2 was located to the north of this, running out of the west baulk. F3 was an oblong stain near the center of the unit. F4 was an irregular dark area in the north-west corner of the unit and F5 was located in the north-east corner. No faunal remains were discovered in this spit.

Layer 2:5 was located $1.20 \mathrm{~m}$ below surface and contained four features. F1 was located along the west wall near the south end of the unit, extending $60 \mathrm{~cm}$ to the east. F2 was an irregular shaped stain that was eventually identified as a human interment (Mortuary Context 6). The feature was c. $1.80 \mathrm{~m}$ in length and a metre wide at its widest part. F3 was also an irregular feature near the north-east corner of the unit that also was discovered to be a human interment (Mortuary Context 7). F3 was $1.30 \mathrm{~m}$ long and $90 \mathrm{~cm}$ wide. F4 was located near the middle of the north baulk and ran for $1.4 \mathrm{~m}$ and extended out $50 \mathrm{~cm}$ toward the south. No faunal remains or artefacts were evident in this spit aside from those in burials.

\section{Layer 3}

The soil colour again changed at c. $126 \mathrm{~cm}$ below surface to a lighter orange colour which represents the natural soil at Phum Sophy. There were a number of burials exposed 
in 3:1 and two other non-burial features. These non-burial features were located in the south-west of the unit. F1 abutted Mortuary Context 5/9 and ran into the west baulk. F2 occupied the south-west corner of the unit. In 3:1 Mortuary Context 5 was exposed and an adjacent mortuary feature to the north of Mortuary Context 5, labelled as Mortuary Context 9. Further to the north of this was Mortuary Context 6 and further north still, Mortuary Context 7 , both running out of the east baulk. Mortuary Context 8 was uncovered in the north-west corner of the unit. No faunal remains were recovered in this spit other than those found in mortuary contexts. This would indicate that the layer predates occupation activity and the burials have been cut into this natural soil.

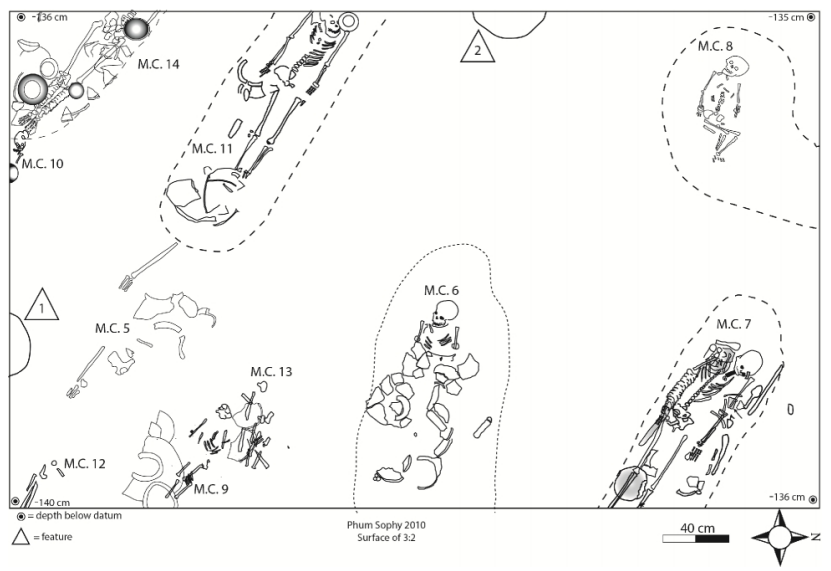

Figure 8: Plan of Unit 2 Layer 3:2, Sophy, showing location of Mortuary Contexts.

The soil colour was unchanged in spit 2 of Layer 3 (Figure 8). Two features were uncovered in this spit as well as Mortuary Context 10 (coming out of the southern baulk), Mortuary Context 11 (running out of the west baulk near the south end of the unit), Mortuary Context 13, (a partial burial along the east baulk) and Mortuary Context 14 in the extreme south-west corner of the unit. Aside from the remains in mortuary contexts, no faunal remains were found in this final spit. Excavation was terminated at c. $146 \mathrm{~cm}$ below ground surface as no further evidence of cultural material was encountered and the matrix was determined to be natural deposit.

\section{PHUM SOPHY MORTUARY ASSEMBLAGE}

Fourteen mortuary contexts containing the remains of 20 individuals were uncovered in the two seasons of excavation. The burial assemblage comprised 12 adults and eight sub-adults, of which sex could be determined in seven individuals. Osteological analysis was conducted on the excavated human remains as well as a selection of looted remains stored in a stupa on the grounds of Chrom Prasat Sophy. The information gathered included data on stature, age, and sex. Preliminary data has been published (Newton et al. 2013, Domett et al. 2013) and more detailed information pertaining to health and pathology will be presented in a forthcoming publication.

\section{Mortuary Context 1}

In the southwestern section of 2:2 a collection of human remains in association with a scatter of ceramic sherds and a post mould was uncovered. There was no apparent grave cut and the human remains that were exposed c. $130 \mathrm{~cm}$ below surface comprised more than one individual. The remains were labelled in post-excavation analysis as Burial 1.0, 1.1 and 1.2 and various additional skeletal material that could not be assigned to any of these skeletons (Figure 9).

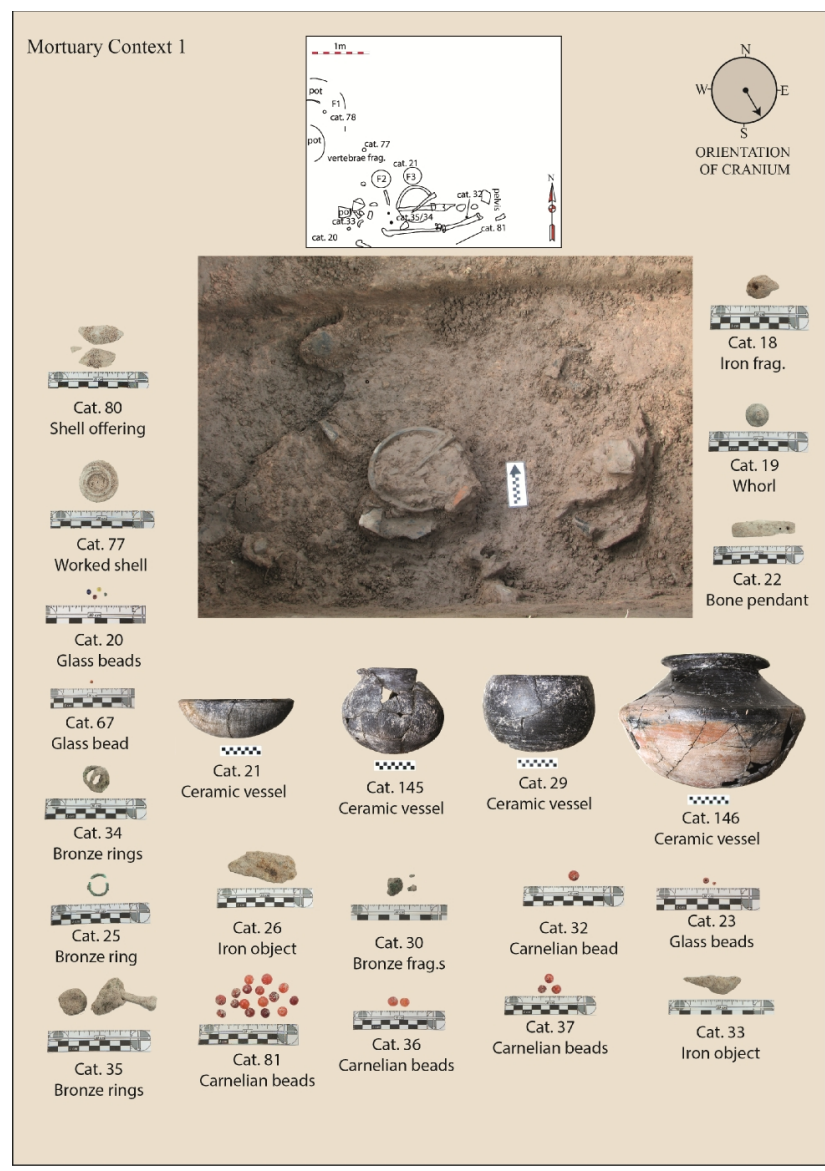

Figure 9: Mortuary Context 1: in situ skeletal material and mortuary assemblage.

\section{Burial 1.0: (adult)}

Bones assigned to this individual are the right and left humeri, an unsided radius, right and left femora, right and left tibiae, right and left fibulae, right clavicle, right and left patellae, and incomplete bones of the left scapula and os coxa. Bones of the hand include six right carpals (hamate, lunate, pisiform, trapezium, capitate and trapezoid), all five right metacarpals, one left metacarpal (MC4), and four right phalanges. Foot bones belonging to the left side include the talus and part of a calcaneus, all five other tarsals, and parts of all five metatarsals; only a partial calcaneus is present for the right foot. Some pieces of left pelvis were identified including parts of the ilium and a pubic bone. Determination of sex was based on the ox coxa. Features included a narrow greater sciatic notch and 
male pubic bone. In addition, most measurements were male when compared with the section point of a large collection of prehistoric Southeast Asian bones. Age-atdeath was estimated to be middle-aged based on the left pubic symphysis, that, although somewhat concreted, was estimated at Grade 4 on the Suchey Brooks scale (scale 16) (Buikstra and Ubelaker 1994).

Burial 1.1: (subadult)

A single tibia was found within Mortuary Context 1 . Based on its length, $145 \mathrm{~mm}$, it was estimated to be from a 2-4-year-old (Buikstra and Ubelaker 1994).

\section{Burial 1.2: (adult)}

The left foot bones included the calcaneus, talus and three other tarsals (navicular, cuboid, intermediate cuneiform) and one metatarsal (MT1). The right foot bones included the calcaneus, talus and four other tarsals (navicular, cuboid, intermediate and medial cuneiform) and parts of three metatarsals and two proximal phalanges. The calcanei of these feet were considerably smaller than those assigned to Burial 1.0. A small piece of ilium with a wide greater sciatic notch suggested this individual was possibly female. There were no skeletal features from which to estimate adult age. There was a number of further adult skeletal remains (mostly axial skeleton) that probably belonged with Burial 1.0 and/or 1.2 but it was not possible to confidently determine which bones belonged with which adult burial.

The material culture associated with these remains included; a bone pendant, a small bronze ring, bronze wire, glass beads, carnelian beads, worked shell, a spindle whorl, two unidentified iron objects and a broken ceramic vessels. Mortuary Context 1 also contained faunal material including; pig (two ribs, three phalanges, two molars, two scapulae and four humeri), cattle (one tibia, one calcaneus, one femur, a humerus, three phalanges, an incisor, a molar and a pelvis fragment), hog deer (a molar, an ulna, an astragalus, a pelvis fragment and two ribs), sambar deer (an antler fragment, a metacarpus and three ribs), a common palm civet humerus, fish and snails.

\section{Mortuary Context 2}

There was no apparent grave cut to indicate the presence of a mortuary context but human remains were exposed at c. $120 \mathrm{~cm}$ below ground surface. Post excavation analysis indicated the presence of more than one individual (Figure 10).

\section{Burial 2.0: (adult, male?)}

The burial included predominantly adult bone comprising; the right temporal bone (with petrous and mastoid), four pieces of ribs, inferior half of the sternum, two metacarpals $\left(1^{\text {st }}\right.$ and $\left.5^{\text {th }}\right)$, coracoid from the right scapula, right clavicle, right humerus, right and left tibiae and fibulae (all partial). The right foot was represented by the talus, intermediate cuneiform and the navicular as well as parts of all five metatarsals and three phalanges. Parts of the left pelvis were present including parts of the iliac blade, auricular surface, acetabulum and ischium. Determination of sex was based on a narrow greater sciatic notch and metrics that suggested these bones were male. It was not possible to estimate the age-at-death beyond 'adult'.

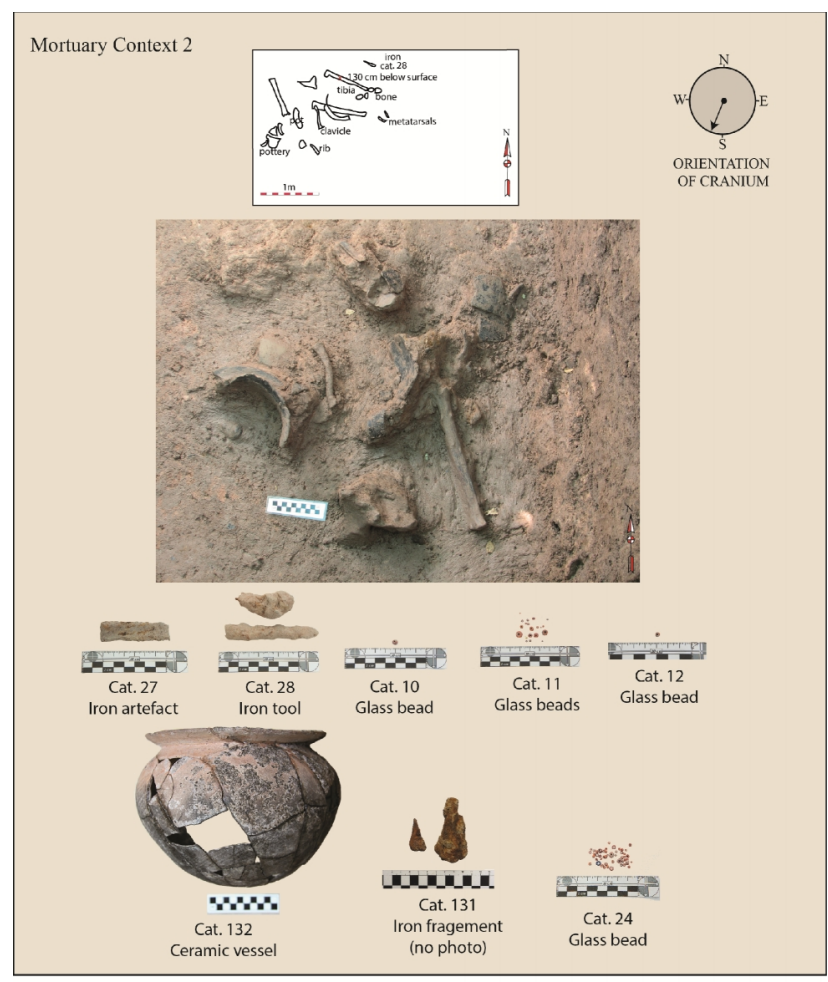

Figure 10: Mortuary context 2: in situ skeletal material and mortuary assemblage.

\section{Burial 2.1: (subadult)}

A second individual was identified comprising a proximal femur (without the epiphysis) and a subadult rib. An estimate of age-at-death was between 6 and 8 years.

Artefacts recovered included ceramic sherds, reconstructed to form a round-bottomed vessel, iron implements, glass beads and fragments of iron. Mortuary Context 2 contained the following faunal material; sambar deer (two molars, a phalanx, a humerus and three ribs), cattle (pelvis fragment), pig (an astragalus, a vertebrae, two humeri and cranial fragments), land and freshwater snail shells.

\section{Mortuary Context 3}

Burial 3.0 (adult) was identified in 1:6 (c. $52 \mathrm{~cm}$ below surface) near the centre of the unit (Figure 11). The mortuary context was quite disturbed, comprising an adult of indeterminate sex. Bones included partial right and left femora, part of a right mandible with two teeth, a loose mandibular premolar, part of the pelvis (acetabulum and ischium) and cranium (left parietal and part occipital) and fragments of other long bones. Overall the bones were moderately gracile. 


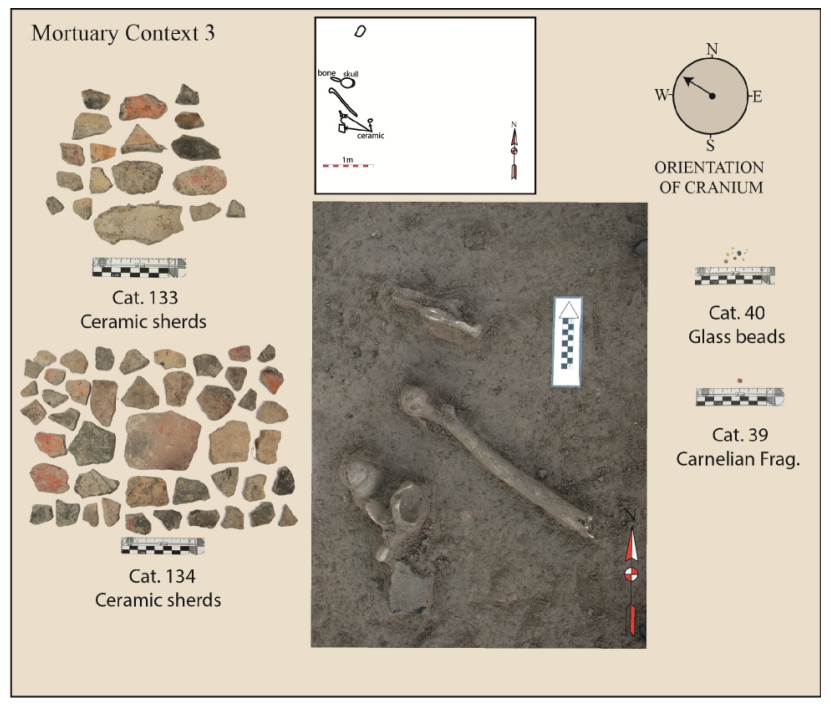

Figure 11: Mortuary Context 3: in situ skeletal material and mortuary assemblage.

Faunal remains associated with Mortuary Context 3 included; hog deer (a humerus and a metacarpal), pig (humerus) and turtle (carapace). The burial assemblage included a carnelian bead fragment, assorted glass beads and two groups of ceramic sherds.

\section{Mortuary Context 4}

Mortuary Context 4 was uncovered in the extension of Unit 1 at c. $130 \mathrm{~cm}$ below surface and contained the remains of an adult of indeterminate sex and an infant, less than a year old (Figure 12).

\section{Burial 4.0: (adult)}

The adult is represented by two pieces of femoral shaft and three incomplete vertebrae (one cervical body and a thoracic and lumbar arch).

\section{Burial 4.1: (subadult)}

The remains ascribed to this individual included some subadult cranial fragments including a partial occipital bone, three pieces of long bone, one rib and a piece of the right ilium. Based on the degree of development of the pars lateralis (of the occipital bone), this subadult was not yet one year of age as the hypoglossal canal was not yet complete (Scheur and Black 2000).

The fill of this grave feature was full of broken ceramics making it appear as if pots were broken into the grave fill at the time of interment. The material culture found in the Mortuary Context included: a shell offering, two pots, a curved iron knife, an iron bangle and fragments, glass beads, two iron projectile points, clay pellets, three unidentifiable iron artefacts, spindle whorls and a bronze fragment. Fauna from Mortuary Context 4 comprised cattle (a pelvic fragment, four ribs and the tibia and ulna), sambar deer (two phalanges, a humerus, a tibia and metacarpus), pig (rib and humerus) and several broken fragments of gastropod shell.

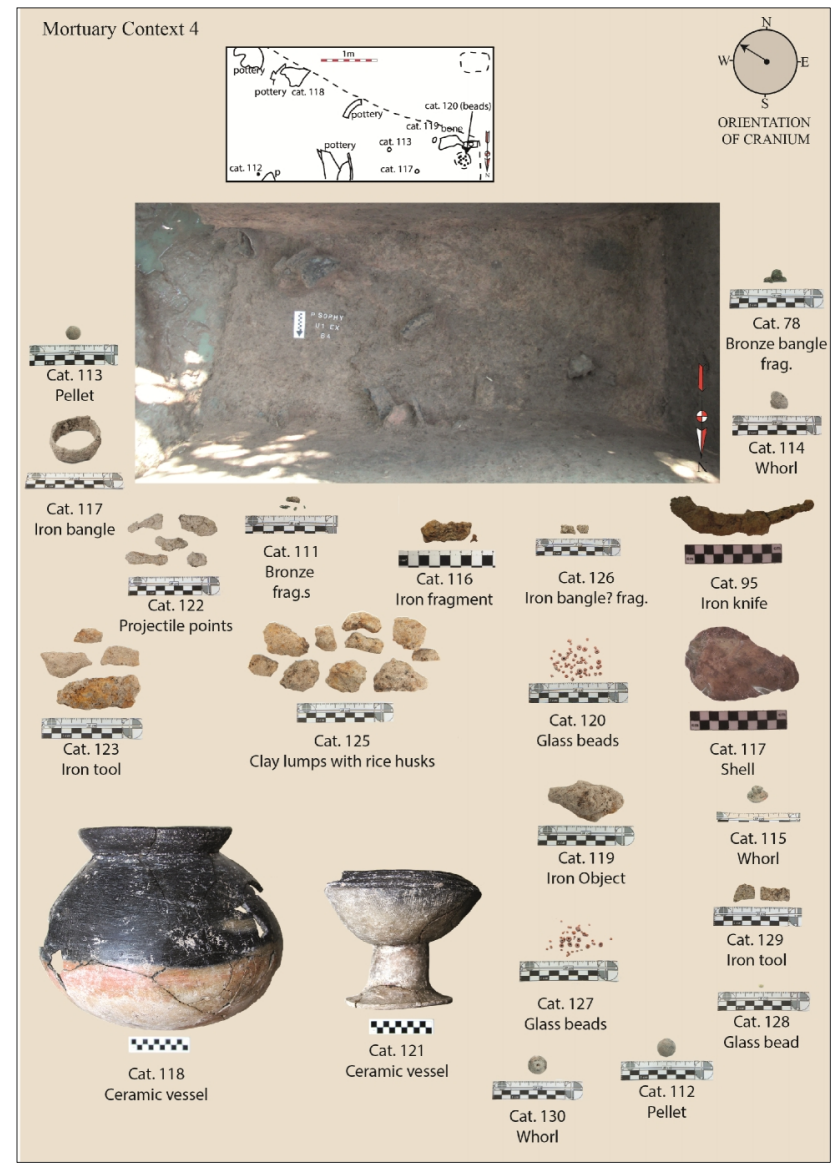

Figure 12: Mortuary Context 4: in situ skeletal material and mortuary assemblage

\section{Mortuary Context 5}

The first of the mortuary contexts discovered during the 2010 excavation was labeled Mortuary Context 5 (the burial numbering system was carried over from the previous year's excavations). The grave cut was apparent c. $120 \mathrm{~cm}$ below surface in Layer 2:5. This mortuary context contains the disturbed and incomplete remains of three adults. In addition, some subadult remains were also found but deemed to belong with Burial 13 during postexcavation analysis. The adults have tentatively been assigned to three individuals (Figure 13).

\section{Burial 5.0: (young adult, female)}

This individual, the most robust of the three, is represented by parts of the left and right os coxae, left patella, right ulna, both clavicles and scapulae, both femoral heads and a range of left and right hand bones. The feet were represented by the right navicular, medial cuneiform and cuboid and the left lateral and medial cuneiforms and cuboid. The right pubic symphysis showed remnants of billowing and the ventral arc just starting to form inferiorly suggesting it belongs to Phase 2 Suchey and Brooks (Buikstra and Ubelaker 1994) and thus a young adult. Morphology of the pubic bone are strongly suggestive of a female skeleton. 


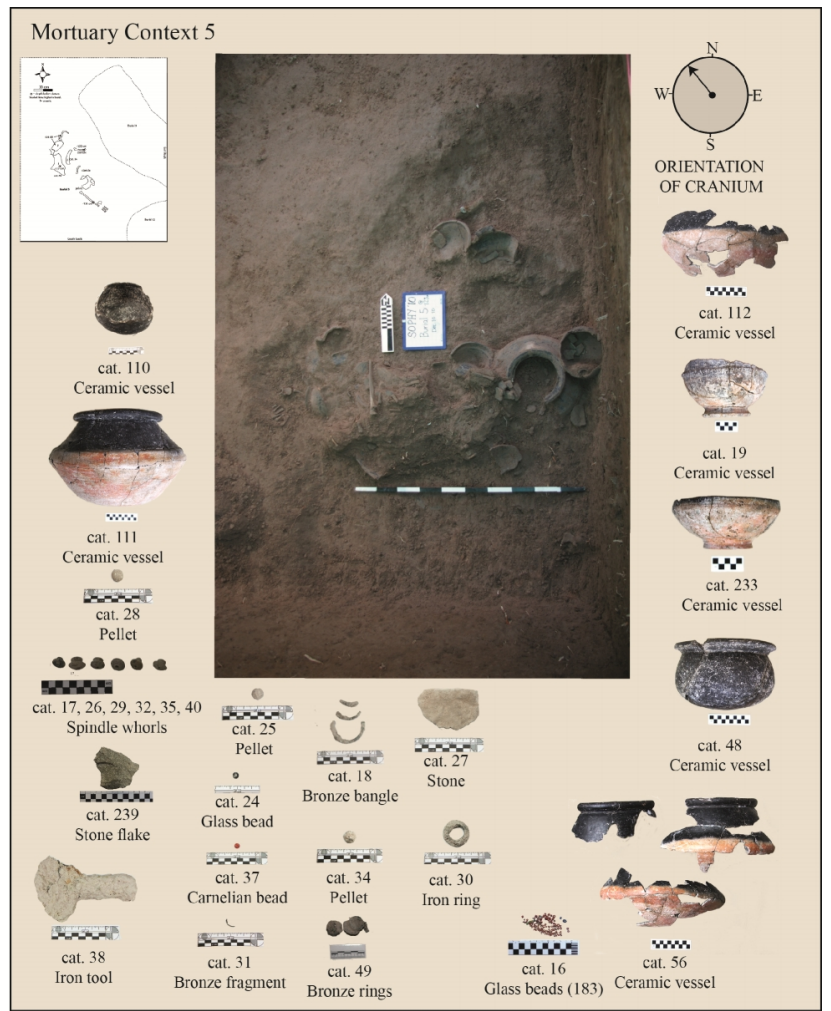

Figure 13: Mortuary Context 5: in situ skeletal material and mortuary assemblage.

Burial 5.1: (adult, unknown sex)

This individual, mid-sized between Burial 5.0 and 5.2, is represented by a right radius and ulna and right hand bones. These remains did not provide information for sex determination or age-at-death estimation.

\section{Burial 5.2: (young adult, unknown sex)}

This individual, the most gracile and possibly youngest, of the three, is represented by a right and left ulnae, the left MC 5 and a right hamate. Also thought to belong is a humeral head and a fifth metacarpal. The right and left zygomata may belong with this person (or Burial 5.1) as could part of the right maxilla and some loose teeth. The maxilla shows evidence of possible ablation. There was also a range of bones and fragments that could belong with any of the three adults.

The degree of mixing in this burial is difficult to explain but may be due to bioturbation as some of the bones had evidence for gnawing by rodents. Also insect nests were found throughout the excavation which could have further displaced the human remains. This burial context also contained cattle (one molar, four femora and a rib) and pig remains (molars, one incisor, 31 skull fragments, five phalanges, three vertebrae, five ribs, 12 humeri, two tibiae and a femur). The material culture found in association with the bones included a broken bronze bangle, spindle whorls, glass beads, ceramic vessels, clay pellets, a stone object, stone flake, an iron ring, a carnelian bead, a hafted iron tool and bronze rings.

\section{Mortuary Context 6}

This interment was discovered to the north of Mortuary Context 5 with the grave cut appearing c. $120 \mathrm{~cm}$ below surface in Layer 2:5. The burial contained the moderately well preserved remains of a child.

\section{Burial 6.0 (subadult)}

The skeleton is very near complete with only the right pelvis, some long bone epiphyses, and a few foot bones missing. The cranium and mandible appeared in good condition with only some parts of the skull base fragmented. Based on dentition and skeletal measurements age-at-death is estimated to be between 5-7 years (Figure 14).

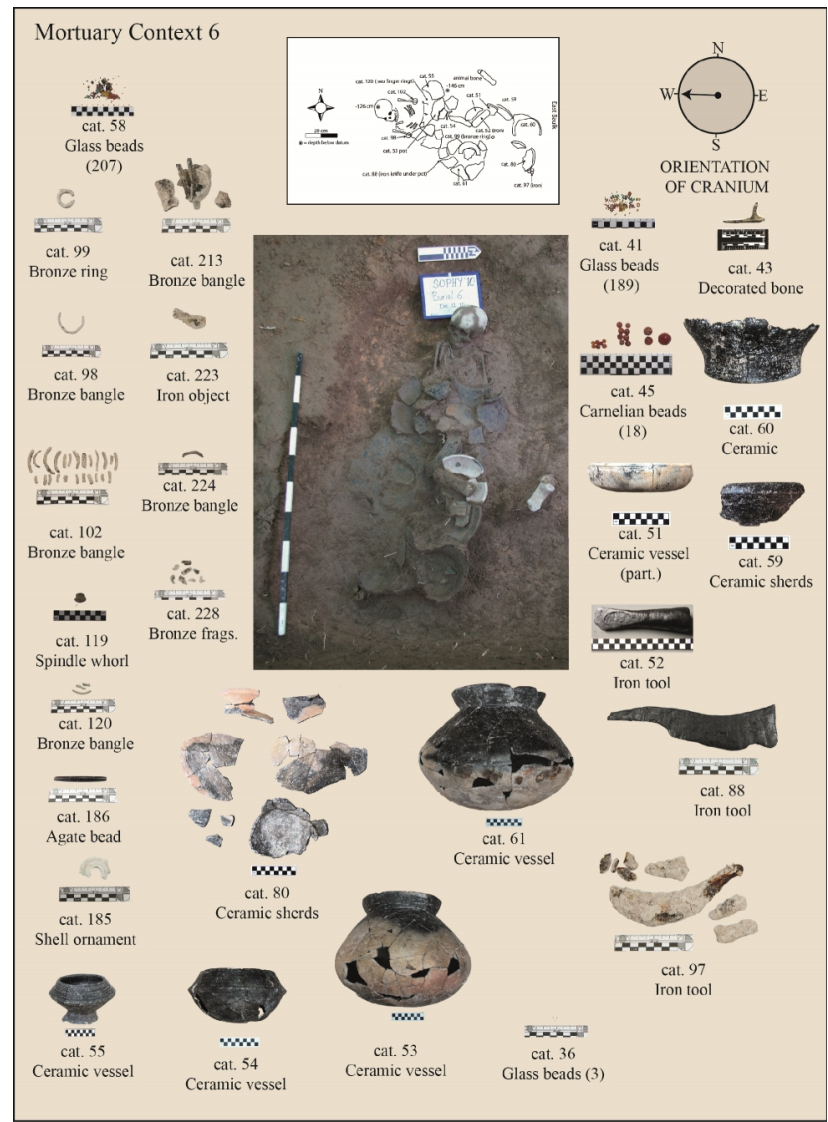

Figure 14: Mortuary Context 6, in situ skeletal material and mortuary assemblage

This individual was interred with a considerable amount of material culture including glass beads, a decorated bone object, ceramic vessels, a spindle whorl, iron tools, a carnelian bead, a bronze bangle, a bronze bangle fragment, a bronze ring, a shell ornament, an agate barrel bead and fragments of a bronze ring. Mortuary Context 6 faunal remains included a muntjak humerus, a buffalo calcanus and six pieces of unidentifiable faunal bone. 


\section{Mortuary Context 7}

The grave cut of this interment was revealed c. $120 \mathrm{~cm}$ below surface in Layer 2:5, located in the north-east corner of the excavation unit, partially embedded in the eastern baulk. Mortuary Context 7 comprised the mostly well preserved, near complete remains of an adult male (Figure $15)$.

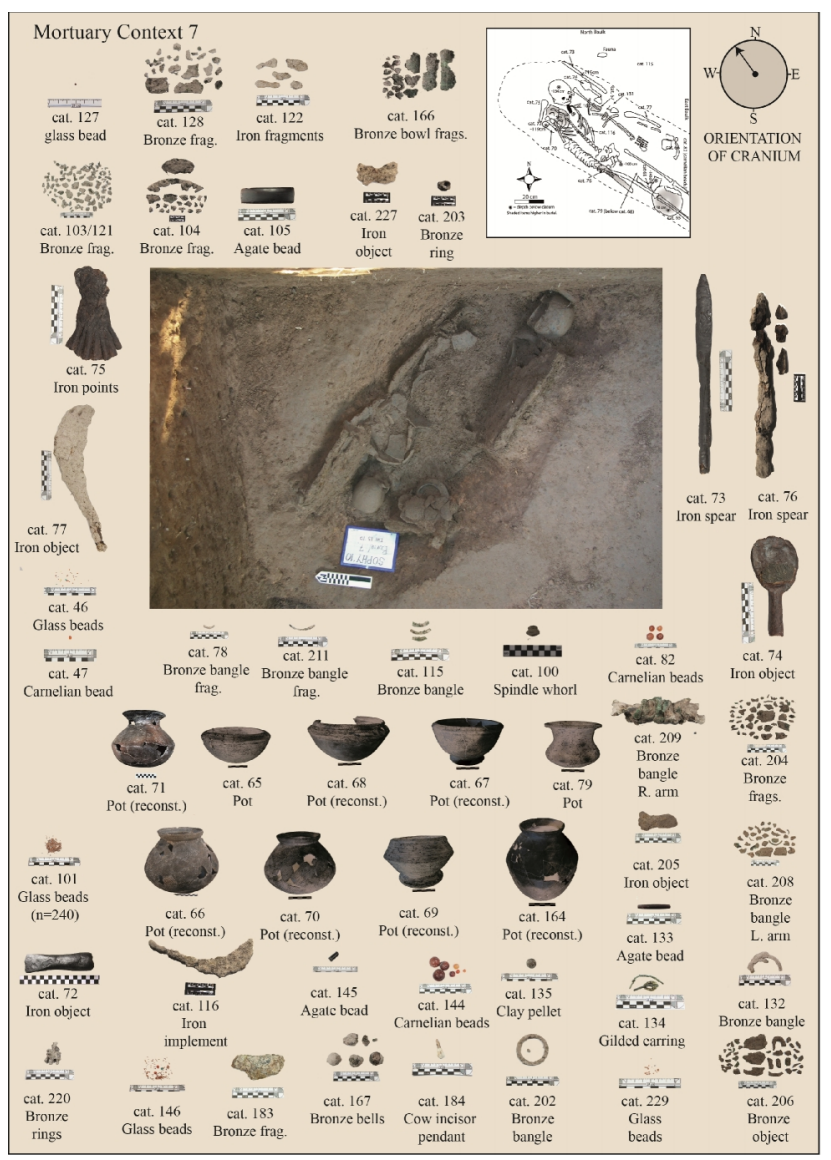

Figure 15: Mortuary Context 7: in situ skeletal material and mortuary assemblage.

Burial 7.0 (adult male)

The skull was in particularly good condition. It was not possible to analyse the right forearm as it was encased in bronze bangles (as was the left forearm, however the left bones were able to be removed from the bangles). Sex was determined to be male based on evidence from the pelvis with supporting evidence from the cranium. There was suspected intentional ablation of both the maxillary lateral incisors.

The individual was accompanied by numerous items of material culture including several ceramic vessels placed atop the body and bronze bangles encasing the left and right arms. A total of eleven vessels were included in the grave. Other material culture included glass beads, carnelian beads, iron knives, a group of iron projectile points, unidentifiable iron tools, a spindle whorl, a bronze bowl, a bronze bangle and additional fragments, a large rectangular agate pendant, an agate barrel bead and a fragment of the same, a gilded bronze earring, a clay pellet, bronze bells, a cattle incisor pendant and a bronze ring from the right hand. The faunal remains included pig remains (humerus, rib, canine, incisor, two skull fragments and a mandible), buffalo (tibia), giant snakehead fish (two skull fragments and three vertebrae), snakehead murrel (four vertebrae), and seventeen unidentifiable faunal bone fragments

\section{Mortuary Context 8}

This interment was uncovered in Layer 3:1 in the northwest corner of the unit c. $130 \mathrm{~cm}$ below surface.

Burial 8.0 (subadult)

The skeleton is near complete and the skull and most long bones were in particularly good condition. Based on dental formation and skeletal measurement the individual was between two and four years-of-age (Figure 16).

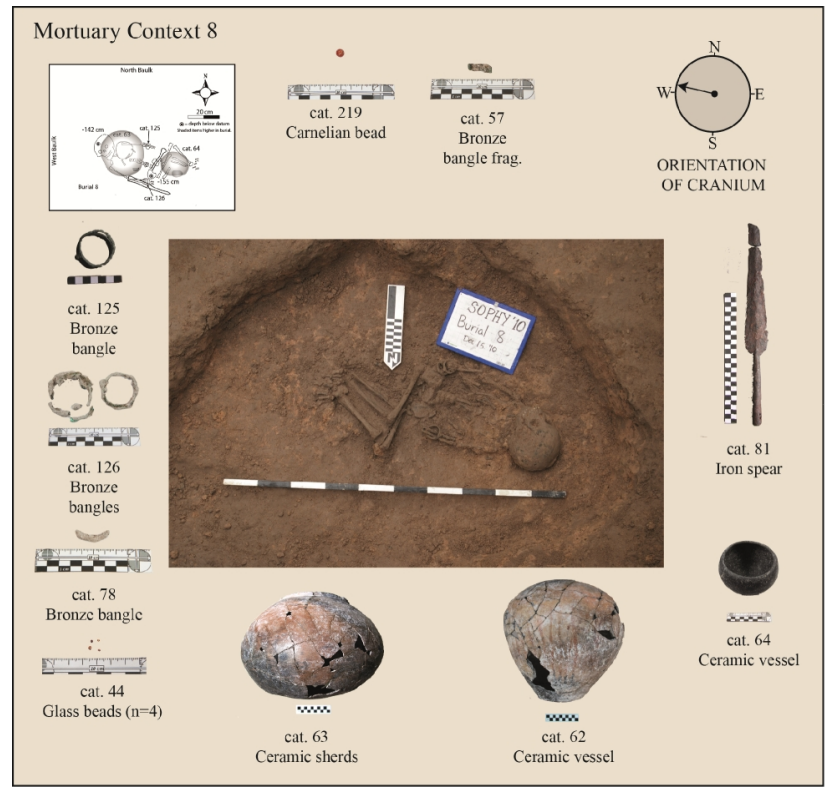

Figure 16: Mortuary Context 8: in situ skeletal material and mortuary assemblage.

The child was buried in a flexed position and had a rather modest complement of material culture including bronze bangles, glass beads, a carnelian bead, an iron spear and three ceramic vessels, one complete and two fragmentary.

\section{Mortuary Context 9}

Mortuary Context 9 was uncovered in the south-eastern section of the 2010 excavation unit in the vicinity of Mortuary Contexts 5 (to the south) and 13 (to the north) c. 130 $\mathrm{cm}$ below surface.

Burial 9.0 (subadult)

While most long bones are at least partly represented, most are in pieces. The cranium is highly fragmented but 
is probably near complete. There are no clavicles or foot bones and only one hand bone. Age-at-death is estimated to be approximately 2.5 years based on dental formation (Figure 17).

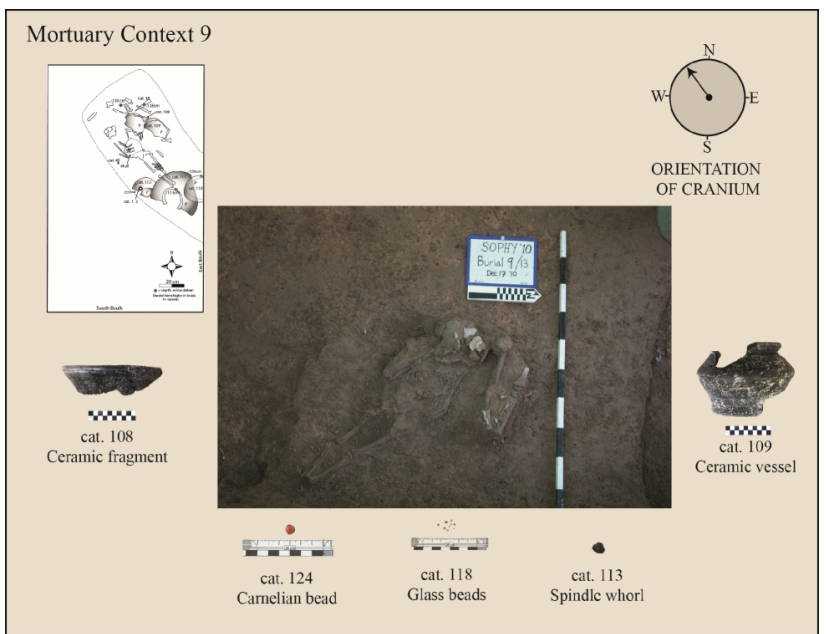

Figure 17: Mortuary Context 9: in situ skeletal material and mortuary assemblage.

Artefacts associated with this mortuary context included broken ceramic vessels, glass beads, a spindle whorl and a carnelian bead. There were no faunal remains associated with this mortuary context.

\section{Mortuary Context 10}

Mortuary context 10 was encountered in Layer 3:2 in the north-west corner of the unit at c. $130 \mathrm{~cm}$ below surface. It contained the remains of a sub-adult estimated to have been between six and nine years of age at death.

\section{Burial 10.0 (subadult)}

The skeleton is near complete though the cranium and many other bones are fragmented. There was also a number of other bones that clearly do not belong with this individual (Figure 18). Age at death was estimated to have been between six and nine years based on dental formation.

The mortuary context contained carnelian and glass beads, a bronze bangle on the left arm, bronze fragments, a bronze bell, ceramic vessels, spindle whorls, an iron projectile point, unidentifiable iron tools, iron fragments and a lump of slag. The mortuary context contained the remains of cattle (humerus, three femora and two ribs), muntjak (phalanx, molar, tibia, calcaneus), catfish (three pieces of cranium, rib and pectoral spine) and 39 pieces of unidentifiable faunal bone.

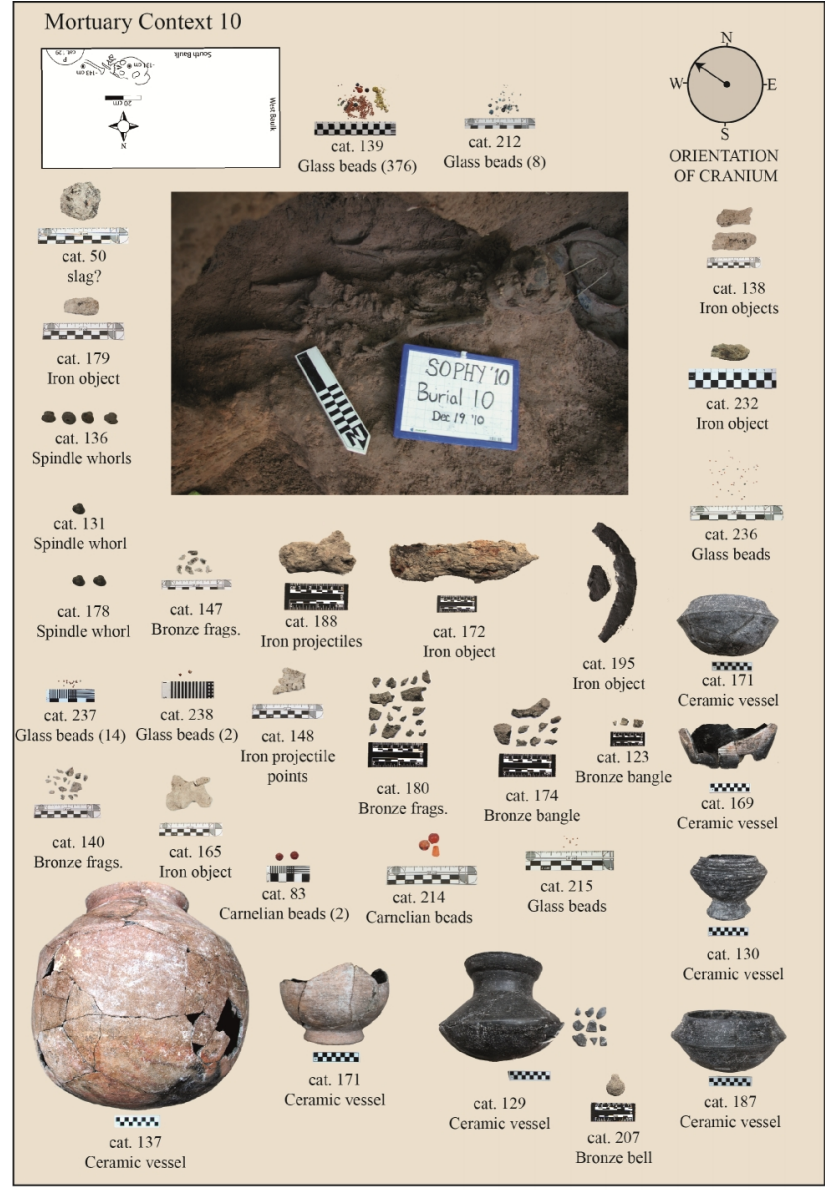

Figure 18: Mortuary Context 10; in situ skeletal material and mortuary assemblage.

\section{Mortuary Context 11}

The grave cut for this mortuary context extended out of the north baulk and was uncovered in Layer 3:1 at c. 130 $\mathrm{cm}$ below surface.

\section{Burial 11.0 (adult female)}

The adult skeleton is near complete with the skull and many long bones in a very good state of preservation. Age-at-death was estimated to be 15-18 years based on the stage of epiphyseal fusion of many bones. Sex estimation was tentatively suggested to be female on the basis of cranial and pelvic morphology (Figure 19).

The mortuary context contained some shell including a large bivalve near the right hand, a lithic core and an iron digging tool. There were two large pots at the feet, a small pot north of the head, two pots south of the right hand, a bronze bangle on the left forearm, bronze rings on the left hand and an iron knife, glass beads around the thorax, one and a half clay pellets and two spindle whorls. Faunal remains included cattle (a femur and carpal bone), a clam shell and snails. 


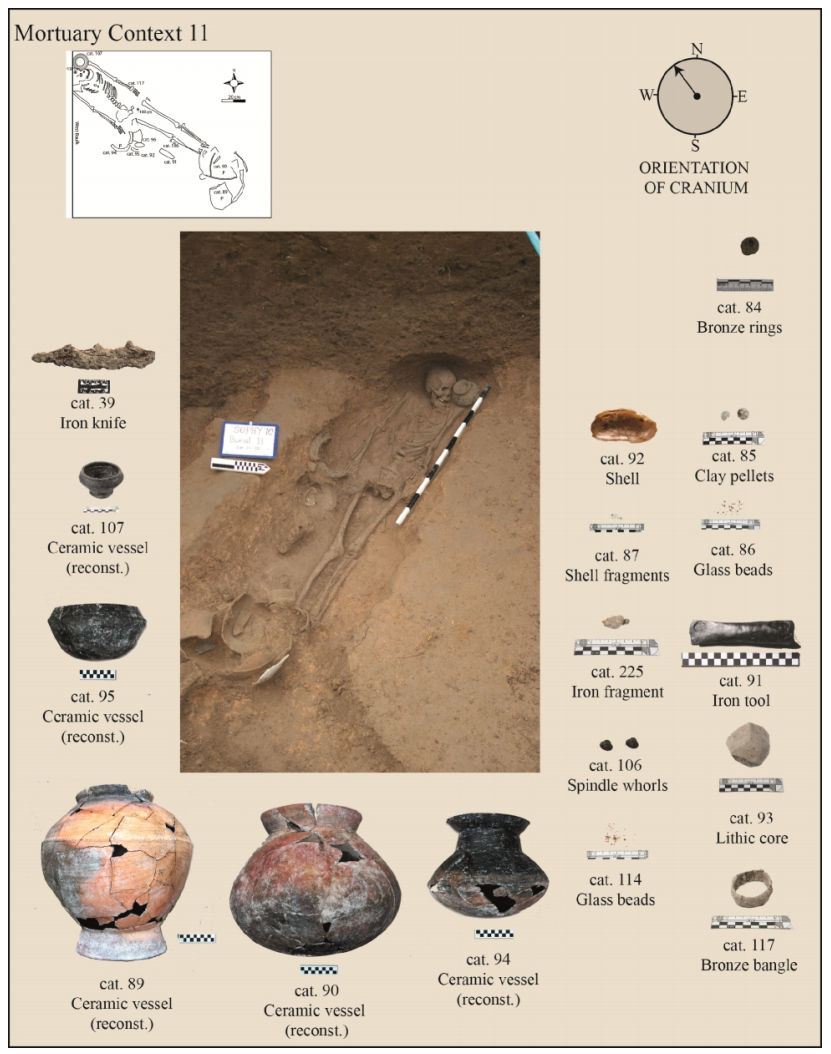

Figure 19: Mortuary Context 11: in situ skeletal material and mortuary assemblage.

\section{Mortuary Context 12}

Mortuary Context 12 appeared in the extreme the southeast corner of the unit in Layer 3:2 at c. $140 \mathrm{~cm}$ below surface and contained the disturbed and incomplete remains of an adult of undetermined sex (Figure 20).

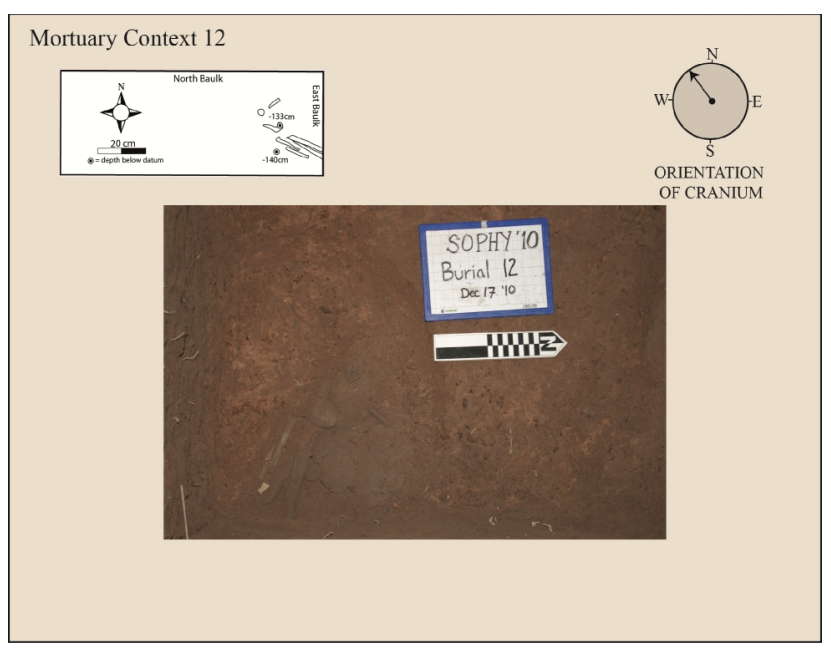

Figure 20: Mortuary Context 12: in situ skeletal material and mortuary assemblage.
Burial 12.0 (adult)

Only part of the burial was uncovered as the rest extended into the baulk. Bones present included fragments and pieces of the cranium, and pieces of upper and lower long bones. There was no information available to allow an accurate age-at-death estimate or sex determination. No grave goods or faunal material were recovered.

\section{Mortuary Context 13}

This mortuary context contained the disturbed and incomplete remains of a subadult who died around two years-of-age (Figure 21). The burial was located just to the north of Mortuary Context 9 . No grave cut was apparent but the human remains were exposed in $3: 2$ at c. 140 cm below surface.

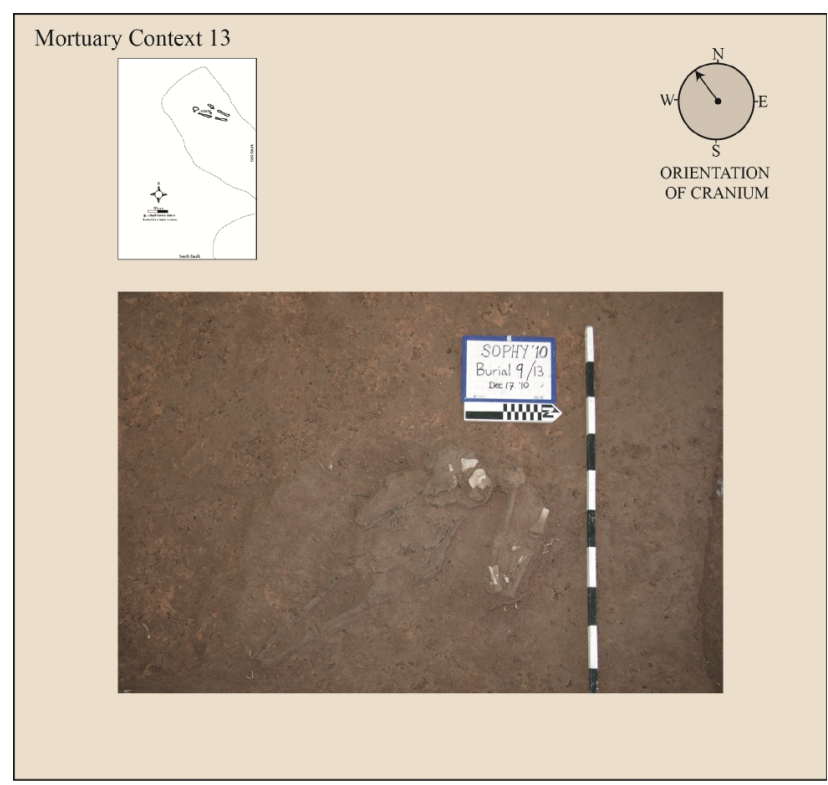

Figure 21: Mortuary Context 13: in situ skeletal material and mortuary assemblage.

\section{Burial 13.0 (subadult)}

Both lower limbs and parts of the upper limbs and pelvis were present along with a piece of mandible, some cranial fragments (possibly parietal), a fragment of vertebral arch and some hand and foot bones. Age at death of this individual was estimated to be between 2-2.5 years based on the development of the dentition. No material culture was associated with the burial but cattle bones (six humeri, a phalanx and a maxilla) were recovered.

\section{Mortuary Context 14}

Burial 14.0 (adult female) was discovered below Mortuary Context 10 in the south baulk with only the the lower limbs protruding from the west baulk. The grave cut was apparent in Layer $3: 1$ c. $130 \mathrm{~cm}$ below surface. The rest 
of the burial was recovered from the baulk ${ }^{2}$ when the excavations were extended (Figure 22). The left forearm was encased in many bronze bangles as were the left and right tibiae and fibulae. Most of the feet were missing. This individual was estimated to have died in middle age. All epiphyses were fused. Pelvic and cranial morphology indicate this individual was female.

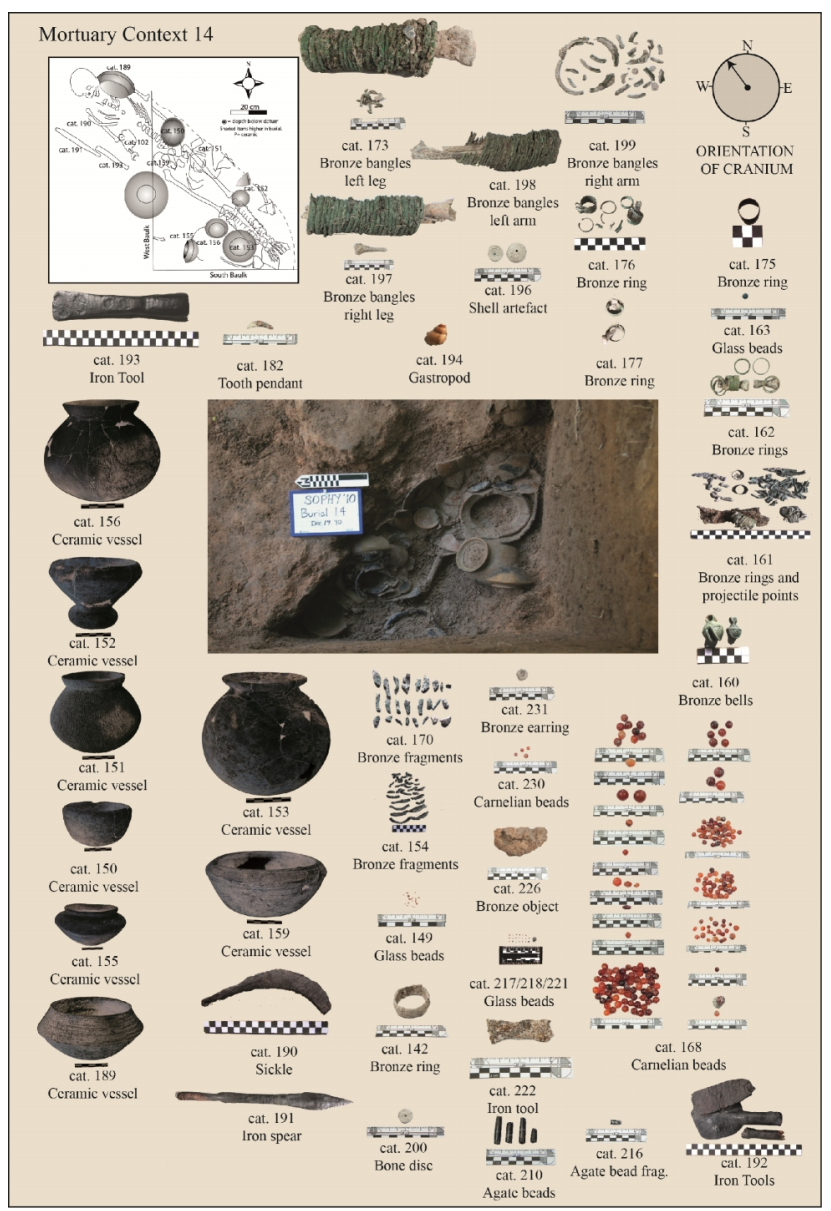

Figure 22: Mortuary Context 14: in situ skeletal material and mortuary assemblage.

Mortuary Context 14 was comparatively wealthy in that several pots were included laid over top of the body. Numerous other artefacts were associated with the burial including 54 bronze rings on both the toes and hands, more than 49 bronze arm bangles, 49 bronze leg bangles, and other bronze bangle fragments, glass beads, 273 carnelian beads, projectile points, a decorative disc, a feline tooth pendant, an iron sickle, an iron knife, and an iron digging implement as well as a gastropod shell and a decorative shell object. The faunal remains found in the burial included a rodent canine, a cattle mandible, and snails.

\footnotetext{
${ }^{2}$ On the recommendation of Cambodian Ministry of Culture and Fine Arts due to concerns the remaining part of the burial would be looted.
}

\section{RADIOCARBON DATING}

Several radiocarbon dates were obtained from samples at Phum Sophy. These include charcoal from Mortuary Context 5 and Mortuary Context 7 and human bone from Mortuary Contexts 5, 6 and 11 (Table 1.).

Table 1: Radiocarbon dates from mortuary contexts.

\begin{tabular}{lllll}
\hline $\begin{array}{l}\text { ANU } \\
\text { sample \# }\end{array}$ & $\begin{array}{l}\text { Mortuary } \\
\text { Context }\end{array}$ & $\mathbf{\delta}^{13} \mathbf{C}$ & ${ }^{14} \mathbf{C}$ age & $\begin{array}{l}\text { Date range (2 } \\
\boldsymbol{\sigma})^{1}\end{array}$ \\
\hline 28423 & $\begin{array}{l}\text { M.C. } 7 \\
\text { (charcoal) }\end{array}$ & -25 & $1800 \pm 40$ & $94-338$ AD \\
28424 & $\begin{array}{l}\text { M.C. } 5 \\
\text { (charcoal) }\end{array}$ & -25 & $1590 \pm 40$ & $392-562$ AD \\
30713 & $\begin{array}{l}\text { M.C. 11 } \\
\text { (human } \\
\text { bone) }\end{array}$ & -18 & $1744 \pm 25$ & $237-380$ AD \\
34107 & $\begin{array}{l}\text { M.C. } 5 \\
\text { (human } \\
\text { bone) }\end{array}$ & -21 & $1845 \pm 25$ & $87-238$ AD \\
30939 & $\begin{array}{l}\text { M.C. } 6 \\
\text { (human } \\
\text { bone) }\end{array}$ & -18.8483 & $1735 \pm 35$ & $230-395$ AD \\
\hline & & & & \\
\hline
\end{tabular}

The severity of looting at the site was made apparent by the large collection of prehistoric human remains stored in a stupa in the monastery compound. Over 130 human skulls and an enormous pile of postcranial skeletal material bears witness to the scale of the heritage destruction at Sophy. In addition to the dates obtained above, samples from the unprovenanced looted material were also analysed (Table 2.). The dates obtained indicate that the human bones are from contexts contemporary to those reported for the excavated material.

Table 2: Radiocarbon dates from unprovenanced remains.

\begin{tabular}{|c|c|c|c|c|}
\hline ANU sample \# & Provenance & $\delta^{13} \mathrm{C}$ & ${ }^{14} \mathrm{C}$ age & $\begin{array}{l}\text { Date range (2 } \\
\sigma)^{3}\end{array}$ \\
\hline 17337 & $\begin{array}{l}\text { Stupa (mandi- } \\
\text { ble -young } \\
\text { adult-sex?) }\end{array}$ & -21.5 & $\begin{array}{l}1620 \pm \\
30\end{array}$ & $380-540$ AD \\
\hline 17336 & $\begin{array}{l}\text { Stupa (long } \\
\text { bone) }\end{array}$ & -16.2 & $\begin{array}{l}1890 \pm \\
30\end{array}$ & $50-220 \mathrm{AD}$ \\
\hline Rafter Sample \# & Provenance & $\delta^{13} \mathrm{C}$ & ${ }^{14} \mathrm{C}$ age & $\begin{array}{l}\text { Date range ( } 2 \\
\sigma)\end{array}$ \\
\hline 5087 & $\begin{array}{l}\text { Stupa (crania } \\
\text { frag.) }\end{array}$ & $\begin{array}{l}- \\
18.453\end{array}$ & $\begin{array}{l}1440 \pm \\
45\end{array}$ & $540-665$ AD \\
\hline 11707 & $\begin{array}{l}\text { Stupa (crania } \\
\text { frag.) }\end{array}$ & -17.3 & $\begin{array}{l}1915 \pm \\
35\end{array}$ & $5-210 A D$ \\
\hline
\end{tabular}

The dates on the human bone from the mortuary contexts suggest a long use of the cemetery, with Mortuary

\footnotetext{
${ }^{3}$ calibrated using OxCal 4.2, Bronk Ramsey, C. (2009). Bayesian analysis of radiocarbon dates. Radiocarbon, 51(1), 337-360.
} 
Context 5 returning a date between the first and third centuries $\mathrm{AD}$ and Mortuary Contexts 6 and 11 dates from the early third century to the late fourth. The charcoal from Mortuary Context 5 returned later dates but may be discounted based on possible errors including in-built age or provenance issues. The samples taken from the stupa returned similar ages with two of the samples falling between the first century to the early third century, while two other samples returned later dates, from the late fourth century to the mid-seventh century $\mathrm{AD}$. If these dates are accurate it may indicate that the practice of interring the dead continued until at least the seventh century, a time when Buddhist and Hindu beliefs had widely been adopted in many parts of Cambodia and saw the widespread adoption of cremation.

\section{MAPPING THE ENVIRONS OF PHUM SOPHY}

As part of the overall project, a mapping project of the landscape surrounding Phum Sophy was undertaken to identify (prehistoric to post-Angkorian period) archaeological remains in this area and to investigate the settlement pattern variability. The study area comprising a $10 \mathrm{~km}$ by $10 \mathrm{~km}$ grid utilized a combination of remotesensing and ground-based data acquisition methodologies. In addition to twelve known sites documented in the national inventory maintained by the Ministry of Culture and Fine Arts, ten additional archaeological sites - seven of them temple sites characteristic of the pre-Angkorian or Angkorian periods - were identified within the study area (Figure 23).

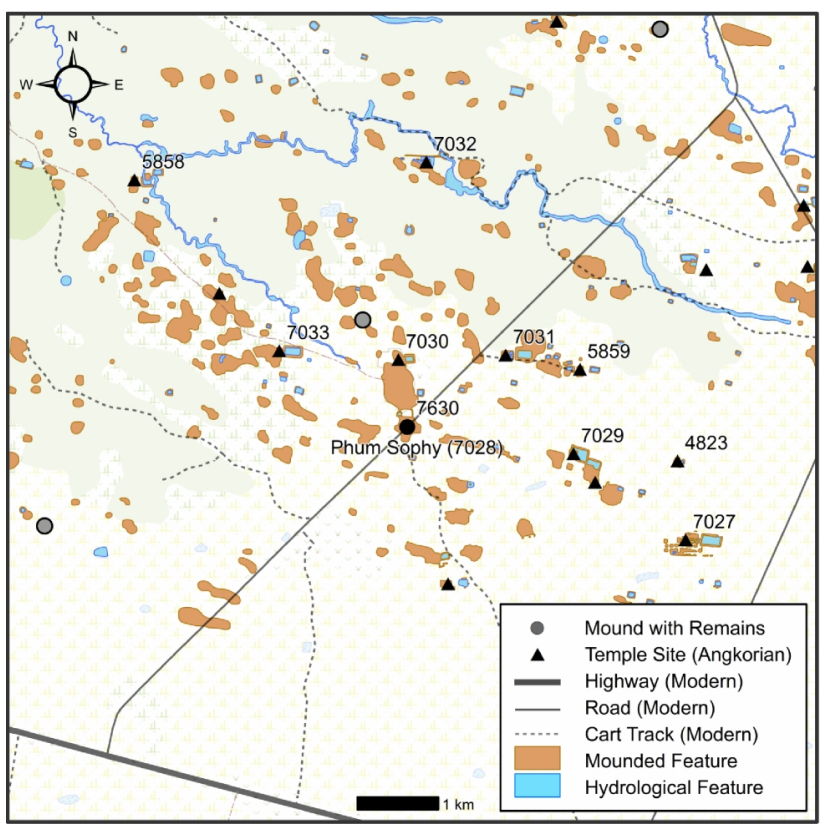

Figure 23: Archaeological sites including mound complexes in the vicinity of Phum Sophy. Labels indicate the inventory number of sites previously documented by the Ministry of Culture and Fine Arts; all other sites were newly-documented during this study.
One of the sites closest to Sophy, identified as site 7030 in the national inventory, represents a ruined temple mound with several courses of brick apparent in the mound and associated pond to the east. The temple sits immediately to north of the Sophy mound and may date to c. 7th century AD. Elsewhere across the study area, there are numerous examples of early-historic and historic period temple sites being apparently superimposed onto large, amorphous mounds of possible prehistoric origin. Although there are occasional examples of this in the Angkor region, in the area around Sophy it appears to be commonplace.

It was concluded from the mapping project that Sophy, rather than being an isolated prehistoric archaeological site, forms part of cluster of archaeological sites with evidence for occupation spanning at least two millennia. The mapping work reveals that, far from being an isolated mound, Sophy is one component of a very extensive and dense distribution of mounds with significant variation in size and shape. Many of these mounds show signs of human origin, occupation or modification, while at the same time the generally northwest-to-southeast alignments and clustering evince some form of relationship with the natural slope and watercourses, which follow the same direction. Further investigation is warranted to more fully understand the nature of this complex archaeological landscape.

\section{PRELIMINARY INTERPRETATIONS}

The excavation of Sophy, conducted over two seasons in 2009 and 2010, has shed light on aspects of life c. 2000 years ago in north-west Cambodia. While analysis of the archaeological material is on-going, it is possible to conclude that Phum Sophy was an agrarian village whose occupants engaged in regional trading networks, metalworking, textile production and, possibly, ceramic production and whose burials reveal differential wealth in terms of their mortuary assemblage.

The inhabitants of Sophy maintained an agricultural economy evidenced by the inclusion of implements such as sickles, knives and hafted digging tools in interments and found throughout the stratigraphy. The faunal remains recovered from the mortuary contexts indicate that the population had access to a broad spectrum of resources and exploited a variety of habitats.

Metal production at the site is suggested by the presence of slag found in Mortuary Context 10 as well in the general spits. Metal items retrieved from the excavations comprised digging and harvesting tools, weaponry, iron and bronze jewellery, bronze bells and bronze vessel fragments. However, there exists no direct evidence such as moulds or smithing paraphernalia to indicate these artefacts were specifically manufactured within Sophy. Evidence for textile production is demonstrated by the presence of spindle whorls. Seventeen whorls were recovered exclusively from mortuary contexts and were highly standardized in their shape, weight, composition and decoration suggesting they were locally made (Cameron 2013). Furthermore, Cameron (2013) noted that the So- 
phy spindle whorl assemblage appeared unique in SE Asia contexts suggesting that the high degree of standardization may represent an intensification of production and possible market supply. The most typologically similar whorls to those at Sophy are found at Tha Kae in central Thailand and are hypothesised to be of Indian origin (Cameron 2011).

The presence of exotic items such as glass, carnelian and agate beads and, possibly, ceramic ware from neighbouring Thailand indicates that the inhabitants of Sophy participated in regional exchange networks. Stone beads crafted from carnelian and agate were found in large quantities in some mortuary contexts. An analysis of the shape and perforation size of these beads places them stylistically to the first few centuries AD (Carter 2012). Similarly, the composition of the glass (high-alumina soda) beads would indicate a date of the same period (Carter 2010, 2012); results which complement the radiocarbon dates obtained for the interments. This period is one in which there appears to be a florescence in cultural exchange between Southeast and South Asia (Bellina and Glover 2014). Analysis completed to date would indicate that the beads found at Sophy may have an Indian origin or suggest the local production of Indian forms. Chemical characterization of the beads may help to distinguish between the two. Other jewellery found at Sophy also suggests contact with Thailand and Vietnam; an opaque disc-shaped orange bead recovered from Mortuary Context 6 is similar to the 'wrapped' beads found commonly in north-east Thai Iron Age assemblages and the long rectangular agate pendant from Mortuary Context 7 is similar to examples unearthed at Oc Eo in southern Vietnam (Carter 2010).

Ceramics similar to the Phimai Black ceramic ware of north-east Thailand Iron Age, typically streak burnished and fired in a reducing atmosphere (Welch 1985), have been found in north-west Cambodia Iron Age deposits. The presence of this ceramic type has been hypothesized to represent a link between the two regions (O'Reilly and Sytha 2001) as either direct imports or as a result of technological transfer between the regions. There is strong similarity in the surface treatment and, in some cases, body shape of the vessels, with those from Sophy showing strong affinity to 'Phimai Black' tradition, both being streak burnished and fired in a reducing atmosphere. Recent research comparing ceramic sherds from Ban Non Wat, a moated site in north-east Thailand with those from Sophy suggests that direct importation (at least from Ban Non Wat) is unlikely and that the vessels may have been manufactured locally. Portable X-ray fluorescence spectroscopic analysis (Ball 2012) and thin-section analysis (Liew 2015) revealed that they were manufactured from a different clay source and differed in rim shape typology.

While detailed skeletal data will be presented in a forthcoming publication aspects of dental health and dental modification have been published (Newton et al. 2013; Domett et al. 2013). There was strong evidence for cultural modification of dentition at Sophy, mostly from the unprovenanced maxillae and mandibles in the bone reli- quary in the local wat, with nearly $50 \%$ of maxillae showing evidence of intentional antemortem removal of anterior teeth. The dates from random samples of these bones indicate that they are contemporaneous to the excavated burials and represent the Iron Age inhabitants of the site. It is clear that some individuals had teeth removed antemortem and others had had their teeth sharpened. The former practice was identified in the Sophy mortuary contexts 5.2 and 7. The practice of dental modification at Sophy and another contemporaneous site, Phum Snay, has been examined by the authors (Domett et al. 2013). The analysis suggests that the patterns of ablation and filing were not strongly associated with a particular sex or age group though the examples of filing at Sophy were limited to the canines. It is possible that the practice of dental modification in this instance may have been a cultural identifier. The purpose of dental modification in ethnographic examples is varied, ranging from status marking, coming of age, marriage, mourning, tribe or family association, ornamentation and beautification (Pietrusewsky and Douglas 1993; Han and Nakahashi 1996; Tayles 1996; Finucane et al. 2008). Group affiliation may have been important during the Iron Age in north-west Cambodia as other skeletal evidence indicates that a significant amount of violence was occurring. In the analysis of the looted skeletal assemblage from Phum Snay, it was observed that over 23 per cent of individuals were affected by some form of cranial trauma (Domett et al. 2011). Internecine warfare may have been a factor in the development of visual cultural markers or have been motivated by the desire to create a menacing visage.

While the sample size is small, the 14 mortuary contexts permit us to make some preliminary comments about variability in the burial treatment of individuals interred at the site (see Table 3). As several of the mortuary contexts contained multiple individuals and some may have been disturbed, it is prudent here to consider only those in which one individual is interred or the complete burial was recovered (Mortuary contexts 3, 6, 7, 8, 10, 11 and 14). Of these, burial orientation was either to the west (three individuals) or north-west (four individuals). While an extensive comparative mortuary assemblage study is presently underway it would appear that only one burial, (Mortuary Context 3) was comparatively impoverished. Two mortuary contexts, namely 7 (an adult male) and 14 (an adult female), contained the largest quantity and most varied assemblage of grave goods. The latter with 273 carnelian beads and both these individuals were the only ones buried with multiple bronze bangles on the arms and legs, and interred with iron spears and projectile points. 
Table 3: Summary of Mortuary Contexts.

\begin{tabular}{|c|c|c|c|c|c|}
\hline Burial & Age & Sex & Grave goods & Fauna & $\begin{array}{l}\text { Burial } \\
\text { Orientation }\end{array}$ \\
\hline 1.0 & $\begin{array}{l}\text { adult } \\
\text { (middle-aged) }\end{array}$ & M & $\begin{array}{l}1 \text { bone pendant } \\
5 \text { bronze rings } \\
7 \text { glass beads } \\
22 \text { carnelian beads }\end{array}$ & $\begin{array}{l}\text { pig } \\
\text { cattle } \\
\text { hog deer } \\
\text { sambar }\end{array}$ & \\
\hline 1.1 & $\begin{array}{l}\text { sub-adult } \\
(2-4 \mathrm{yr})\end{array}$ & $?$ & $\begin{array}{l}1 \text { worked shell object } \\
1 \text { spindle whorl } \\
3 \text { unidentified iron objects } \\
3 \text { bronze fragments }\end{array}$ & $\begin{array}{l}\text { palm civet } \\
\text { fish } \\
\text { snails } \\
\text { dog }\end{array}$ & \\
\hline 1.2 & adult & $\mathrm{F} ?$ & 4 ceramic vessels & bivalve & \\
\hline 2.1 & $\begin{array}{l}\text { adult } \\
\text { sub-adult } \\
\text { (6-8 yr) }\end{array}$ & M & $\begin{array}{l}2 \text { iron implements } \\
1 \text { ceramic vessel } \\
>30 \text { glass beads } \\
\text { iron fragments }\end{array}$ & $\begin{array}{l}\text { sambar deer } \\
\text { cattle } \\
\text { pig } \\
\text { land snail freshwater } \\
\text { snail }\end{array}$ & \\
\hline 3.0 & adult & $?$ & $\begin{array}{l}1 \text { carnelian bead fragment } \\
10 \text { assorted glass beads } \\
2 \text { groups of ceramic sherds }\end{array}$ & $\begin{array}{l}\text { hog deer } \\
\text { pig } \\
\text { turtle }\end{array}$ & W \\
\hline 4.0 & adult & $?$ & $\begin{array}{l}2 \text { ceramic vessels } \\
1 \text { bivalve shell offering } \\
1 \text { curved iron knife } \\
2 \text { clay pellets }\end{array}$ & $\begin{array}{l}\text { cattle } \\
\text { sambar deer } \\
\text { pig } \\
\text { snail }\end{array}$ & W \\
\hline 4.1 & $\begin{array}{l}\text { sub-adult } \\
(<1 \mathrm{yr})\end{array}$ & $?$ & $\begin{array}{l}1 \text { iron bangle }+ \text { frags } \\
3 \text { iron artefacts } \\
3 \text { spindle whorls } \\
\text { bronze fragments } \\
1 \text { bronze bangle fragment } \\
101 \text { glass beads } \\
2 \text { iron projectile points }\end{array}$ & & \\
\hline 5.0 & young adult & $\mathrm{F}$ & $\begin{array}{l}1 \text { broken bronze bangle, } \\
6 \text { spindle whorls } \\
184 \text { glass beads } \\
7 \text { ceramic vessels }\end{array}$ & $\begin{array}{l}\text { cattle } \\
\text { pig }\end{array}$ & NW \\
\hline 5.1 & adult & $?$ & $\begin{array}{l}3 \text { clay pellets } \\
1 \text { sandstone fragment } \\
1 \text { iron ring }\end{array}$ & & \\
\hline 5.2 & young adult & $?$ & $\begin{array}{l}1 \text { carnelian bead } \\
1 \text { hafted iron tool } \\
5 \text { bronze rings } \\
1 \text { lithic flake }\end{array}$ & & \\
\hline 6.0 & $\begin{array}{l}\text { sub-adult } \\
\text { (5-7 yr) }\end{array}$ & $?$ & $\begin{array}{l}399 \text { glass beads } \\
1 \text { decorated bone object } \\
8 \text { whole and partial ceramic vessels } \\
1 \text { spindle whorl } \\
3 \text { iron tools } \\
18 \text { carnelian bead } \\
5 \text { bronze bangle }+ \text { fragments } \\
1 \text { bronze ring }+ \text { fragments } \\
1 \text { shell ornament } \\
1 \text { agate barrel bead }\end{array}$ & $\begin{array}{l}\text { muntjak } \\
\text { buffalo }\end{array}$ & W \\
\hline 7.0 & adult & $M$ & $\begin{array}{l}>300 \text { glass beads } \\
\text { bronze fragments } \\
\text { iron fragments } \\
1 \text { bronze bowl (broken) } \\
1 \text { agate bead } \\
\text { iron object } \\
1 \text { bronze ring } \\
\text { several iron projectile points } \\
4 \text { iron implements } \\
2 \text { iron spears } \\
12 \text { carnelian bead } \\
6 \text { bronze bangle }+ \text { fragments } \\
1 \text { spindle whorl } \\
9 \text { ceramic vessels } \\
1 \text { agate bead } \\
1 \text { clay pellet } \\
1 \text { gilded earring }\end{array}$ & $\begin{array}{l}\text { pig } \\
\text { buffalo } \\
\text { Fish: giant snakehead; } \\
\text { snakehead murrel }\end{array}$ & NW \\
\hline
\end{tabular}




\begin{tabular}{|c|c|c|c|c|c|}
\hline & & & $\begin{array}{l}\text { bronze rings } \\
4 \text { bronze bells } \\
1 \text { cow incisor pendant }\end{array}$ & & \\
\hline 8.0 & $\begin{array}{l}\text { sub-adult } \\
\text { (2-4 yr) }\end{array}$ & $?$ & $\begin{array}{l}4 \text { glass beads } \\
4 \text { bronze bangle }+ \text { fragments } \\
1 \text { iron spear head } \\
3 \text { ceramic vessels } \\
1 \text { carnelian bead }\end{array}$ & $\begin{array}{l}2 \text { piece unidentified fauna } \\
\text { snakehead murrel }\end{array}$ & W \\
\hline 9.0 & $\begin{array}{l}\text { sub-adult } \\
\text { (2.5 yr) }\end{array}$ & ? & $\begin{array}{l}1 \text { ceramic vessel + fragment of other } \\
9 \text { glass beads } \\
1 \text { spindle whorl } \\
1 \text { carnelian bead }\end{array}$ & no fauna & NW \\
\hline 10.0 & $\begin{array}{l}\text { sub-adult } \\
\text { (6-9 yr) }\end{array}$ & & $\begin{array}{l}5 \text { carnelian beads } \\
>400 \text { glass beads } \\
\text { a bronze bangle } \\
\text { bronze fragments } \\
1 \text { bronze bell } \\
7 \text { ceramic vessels } \\
7 \text { spindle whorls } \\
4 \text { iron projectile point } \\
5 \text { iron objects, iron fragments } \\
\text { a lump of slag }\end{array}$ & $\begin{array}{l}\text { cattle } \\
\text { muntjak } \\
\text { catfish }\end{array}$ & NW \\
\hline 11.0 & $\begin{array}{l}\text { adult } \\
\text { (15-18 yr) }\end{array}$ & $F ?$ & $\begin{array}{l}\text { large bivalve (Unionidae Alasmidonta) } \\
\text { a lithic core } \\
1 \text { iron tool } \\
1 \text { bronze bangle } \\
3 \text { bronze rings } \\
1 \text { iron knife } \\
98 \text { glass beads } \\
1.5 \text { clay pellets } \\
2 \text { spindle whorls } \\
5 \text { ceramic vessels }\end{array}$ & $\begin{array}{l}\text { cattle } \\
\text { clam } \\
\text { snails }\end{array}$ & NW \\
\hline 12.0 & adult & $?$ & no grave goods & no fauna & NW \\
\hline 13.0 & sub-adult (2-2.5 yr) & & no grave goods & cattle & \\
\hline 14.0 & adult & $\mathrm{F}$ & $\begin{array}{l}8 \text { ceramic vessels } \\
54 \text { bronze rings on toes and hands } \\
9 \text { glass beads } \\
273 \text { carnelian beads } \\
1 \text { agate bead fragment } \\
>40 \text { glass beads } \\
25 \text { bronze right leg bangles } \\
24 \text { bronze bangles left leg } \\
>49 \text { bronze arm bangles } \\
3 \text { projectile points } \\
1 \text { decorative bone disc } \\
1 \text { feline tooth pendant } \\
1 \text { iron sickle } \\
1 \text { iron spear } \\
2 \text { iron implements } \\
1 \text { gastropod shell } \\
1 \text { decorative conus shell }\end{array}$ & $\begin{array}{l}\text { cattle } \\
\text { snails } \\
\text { rodent }\end{array}$ & NW \\
\hline
\end{tabular}




\section{CONCLUSION}

The 2009 and 2010 season at Sophy uncovered an Iron Age (c. 87-526 AD) agricultural village. Excavation revealed a total of 14 mortuary contexts (comprising 20 individuals). The burial population included 12 adults, of which the sex could be determined for only seven (three males and four females) and eight sub-adults. The dead were interred with a range of material culture including ceramic vessels, iron and bronze artefacts, bronze jewellery, stone and glass beads. Given the interments are situated just above the natural soil it appears that the human remains represent the first occupants of the site. The layers above the mortuary levels at Sophy rendered Indianinfluenced artefacts such as fragments of kendi pots indicating post-prehistoric occupation of the site, and the site continues to be occupied today. Detailed analyses of the material culture and human remains will form the basis of future publications.

\section{ACKNOWLEDGEMENTS}

This research was made possible through a grant by the Australian Research Council: Discovery Project (DP0984968) and the kind cooperation of the Ministry of Culture and Fine Arts of Cambodia. We would like to thank in particular, H.E. Ham Kim Son, H.E. Oung Ouen, the Governor of Banteay Meanchey Province, Mr Norm, Pen Phiwath, Ok Sokha, Cheang Vuthy, Suy Pov, So Malay, Tep Sokha, Huot Samnang, David Brotherson, students from the Royal University of Fine Arts (Phnom Penh), Hen Chenda, Pelle Wijker and Stephane De Greef and the staff at the Robert Christie Research Centre and, of course, the villagers of Sophy.

\section{BIBLIOGRAPHY}

Ball, A. 2012. Frameworks for Thai-Cambodian Ceramic Diffusion: An examination of earthenware rims from northeastern Thailand and northwestern Cambodia. Honours Thesis, The Australian National University, Canberra.

Bellina, B. and I. Glover. 2004. The archaeology of early contact with India and the Mediterranean world, from the fourth century BC to the fourth century AD, in Southeast Asia: From Prehistory to History, eds. I. Glover and P. Bellwood. New York: Routledge Curzon, 68-87.

Bronk Ramsey, C. 2009. Bayesian analysis of radiocarbon dates. Radiocarbon, 51 (1), 337-360.

Buikstra, J. and D. Ubelaker. (eds). 1994. Standards for Data Collection from Human Skeletal Remains. Arkansas Archaeological Survey: Fayetteville, Arkansas; 206 p.

Cameron, J. 2011. Iron and cloth across the Bay of Bengal: new data from Tha Kae, central Thailand. Antiquity 85:559567.

Cameron, J. 2013. Report on an analysis of an assemblage of spindle whorls from Phum Sophy, Cambodia. Unpublished Report.

Carter, A. 2010. Trade and Exchange Networks in Iron Age Cambodia: Preliminary Results from a Compositional Analysis of Glass Beads, Bulletin of the Indo-Pacific Prehistory Association 30: 178-188.
Carter, A. 2012. Stone and Glass beads from Phum Sophy: A preliminary report. Unpublished report.

Domett, K. M. and J. Newton, D. O'Reilly, N. Tayles, L. Shewan, N. Beavan. 2013. Cultural modification of the dentition in prehistoric Cambodia. International Journal of Osteoarchaeology 22: 274-286.

Domett, K. M. and D. O'Reilly, H. Buckley, 2011. Bioarchaeological Evidence of Conflict in Iron Age, Northwest Cambodia. Antiquity 85 (328):441-458.

Finucane, B. C. and K. Manning, M. Touré. 2008. Prehistoric dental modification in West Africa- early evidence from Karkarichinkat Nord, Mali. International Journal of Osteoarchaeology 18 (6): 632-640. DOI: 10.1002/oa.957

Han, K. and Nakahashi T., 1996. A comparative study of ritual tooth ablation in ancient China and Japan. Anthropological Science 104 (1): 43-64.

Liew, S. 2015. Pottery Technology of Iron Age Cambodia: a thin section analysis of earthenware rim sherds from Phum Sophy, Cambodia. M.A. Thesis, The Australian National University, Canberra.

Newton J. and K. Domett, D. O'Reilly, L. Shewan. 2013. Dental health in Iron Age Cambodia: Temporal variations with rice agriculture. Journal of Paleopathology 3 (1):1-10.

O'Reilly, D. and S. Pheng. 2001. Recent Excavations in Northwest Cambodia. Antiquity 75:265 - 66.

Pietrusewsky M. D. and Douglas 1993. Tooth ablation in old Hawai'i. Journal of the Polynesian Society, 102:255 272.

Scheur, L. and S. Black. 2000. Developmental Juvenile Osteology. Academic Press.

Tayles N. 1996. Tooth ablation in prehistoric Southeast Asia. International Journal of Osteoarchaeology $6: 333$ - 345 .

Welch, D. 1985. Adaptation to Environmental Unpredictability: Intensive Agriculture and Regional Exchange at Late Prehistoric Centres in the Phimai Region in Thailand. Ph.D thesis, University of Hawai'i, Manoa, United States. 